Sabrina Nasser de Carvalho

\title{
DIREITO DE DEFESA NOS CONFLITOS FUNDIÁRIOS PLURISSUBJETIVOS
}

\author{
TESE DE DOUTORADO
}

Orientador: Professor Associado Dr. Ricardo de Barros Leonel

UNIVERSIDADE DE SÃO PAULO

FACULDADE DE DIREITO

São Paulo - SP

2018 



\title{
Sabrina Nasser de Carvalho
}

\section{DIREITO DE DEFESA NOS CONFLITOS FUNDIÁRIOS PLURISSUBJETIVOS}

\begin{abstract}
Tese de Doutorado, apresentada à Banca Examinadora do Programa de Pós-Graduação em Direito, da Faculdade de Direito da Universidade de São Paulo, como exigência parcial para obtenção do título de Doutor em Direito, na área de concentração de Direito Processual, sob orientação do Professor Associado Doutor Ricardo de Barros Leonel.
\end{abstract}

\author{
UNIVERSIDADE DE SÃO PAULO \\ Faculdade de Direito \\ São Paulo




C331 CARVALHO, Sabrina Nasser de.
Direito de Defesa nos Conflitos Fundiários Plurissubjetivos. Sabrina Nasser de
Carvalho - São Paulo, 2018. 407 p.
Tese (Doutorado). Programa de Pós-Graduação em Direito - Faculdade de
Direito da Universidade de São Paulo.
Orientador: Prof. Associado Dr. Ricardo de Barros Leonel
1. Processo Civil. 2. Processo Coletivo. 3. Conflitos fundiários. 4. Procedimento
diferenciado. I. Título.




\author{
Sabrina Nasser de Carvalho
}

\title{
DIREITO DE DEFESA NOS CONFLITOS FUNDIÁRIOS PLURISSUBJETIVOS
}

Tese de Doutorado, apresentada à Banca Examinadora do Programa de Pós-Graduação em Direito, da Faculdade de Direito da Universidade de São Paulo, como exigência parcial para a obtenção do título de Doutor em Direito, na área de concentração de Direito Processual, sob orientação do Professor Associado Doutor Ricardo de Barros Leonel.

Banca Examinadora:

Prof(a). Dr(a).

Prof(a). Dr(a).

Prof(a). Dr(a).

Prof(a). Dr(a).

Prof(a). Dr(a).

São Paulo

2018 

Ao Rafa e ao Francisco, meus amores. 



\section{AGRADECIMENTOS}

Agradeço ao meu orientador, Ricardo de Barros Leonel, pela profícua parceria, que se iniciou em 2010, quando ingressei no mestrado. Ao longo destes anos, a confiança em mim depositada e a liberdade que sempre me ofertou para expor a minha perspectiva sobre o objeto de pesquisa foram o impulso que eu precisava para que conseguisse traçar as metas e, principalmente, para que eu conseguisse alcançá-las.

À professora Susana Henriques da Costa, por também fazer parte de toda minha formação acadêmica, já que, além de minha professora, se fez presente em todas as bancas de qualificação e de defesa do mestrado e do doutorado. Seus ensinamentos, reflexões e críticas concorreram e muito para a minha adoração à pesquisa.

Ao professor Marcelo Bonício, pelas valiosas e sempre pertinentes críticas feitas no exame de qualificação.

A todos os integrantes do Núcleo de Habitação e Urbanismo da Defensoria Pública, das diversas composições das quais participei. Foi lá que compreendi, na prática, o que representa a violação à moradia e a importância dos movimentos sociais na luta para um país mais justo. Tempos saudosos, em que amadureci e me transformei enquanto defensora pública.

Aos meus amigos, sempre presentes, que fazem a minha vida ser mais leve e muito mais divertida. Faço um agradecimento especial ao Allan, minha dupla de trabalho, que nunca mediu esforços para me ajudar e para que eu conseguisse lidar com meus inúmeros papéis na vida.

Aos meus pais e sogros, porque foram peças essenciais neste trabalho, ainda que indiretamente. $\mathrm{O}$ amor incondicional de avó e de avô tranquilizou o meu coração quando tinha que me ausentar do lazer com o Francisco para me dedicar aos estudos. Vê-lo feliz, na amável companhia dos avós, me revigorava para rebater o cansaço e iniciar os estudos.

Ao Rafa, meu maior incentivador! Do seu lado, as grandes dificuldades se esvaem e tudo fica mais simples e agradável! Nunca canso de repetir: estar ao seu lado durante a elaboração deste trabalho foi fundamental para concretizá-lo! 



\section{RESUMO}

Os conflitos fundiários, malgrado terem sempre acompanhado a história da humanidade, recebem atualmente ampla atenção de todos os Poderes, tamanho tem sido o impacto no meio rural ou urbano, inclusive resultando em ampla violência. As soluções passam pela atuação em diversas frentes, mas, inegavelmente, por políticas públicas que concorram para uma distribuição mais justa e equânime de terras e moradia. Quando os conflitos se tornam litígios e deságuam no Poder Judiciário, percebe-se uma dificuldade também deste Poder em tratar o embate com as particularidades e complexidades que o perfaz, a fim de que o provimento judicial seja mais justo e, consequentemente, para se alcançar outros escopos do processo, como a própria pacificação social. Com vistas a atingir este desiderato, deposita-se ampla expectativa no procedimento, de modo que este possa abarcar todos os elementos que integram e constituem o conflito, acompanhando, assim, as complexidades inerentes a esta modalidade de litígio. As dificuldades se acirram quando se analisa o litígio sob a perspectiva das situações jurídicas passivas, portanto, quando uma coletividade é demandada a desocupar determinada área. Como construir um modelo procedimental que respeite as garantias processuais de uma multidão que terá seu patrimônio jurídico diretamente atingido? Os Tribunais, atualmente, têm respondido tais demandas utilizando-se de mecanismos tradicionais, pelo viés estreito e limitado da processualística individual. O escopo deste trabalho é demonstrar o quão limitada tem sido esta visão e, posteriormente, fazer propostas para que o instrumento processual esteja à altura do objeto que lhe é subjacente.

PALAVRAS CHAVES: conflitos fundiários - litígios coletivos passivos - processo estrutural

Autora: Sabrina Nasser de Carvalho. Título: Direito de Defesa nos Conflitos Fundiários Plurissubjetivos. Páginas: 407. Doutorado. Faculdade de Direito, Universidade São Paulo, São Paulo, julho de 2018. 



\begin{abstract}
In spite of having always been present in the history of humanity, land conflicts are currently receiving wide attention from all powers so huge has been the impact it has had on rural or urban areas, even resulting in widespread violence. Solutions go through actions on different fronts; undeniably by public policies that contribute to a fairer and more equitable distribution of land and housing. When disputes become litigations and fall into the judiciary system, it is noticeable how difficult it is for the system to deal with the particularities that encompass them, especially concerning the expectations that they have for a fair decision and that the legal action reaches scopes of other nature, such as social pacification itself. In order to achieve this, there is a broad expectation in the procedure so that it can cover all the elements that make up and constitute the conflict, therefore following the complexities inherent in this type of litigation. Difficulties worsen when analyzing the litigation from the perspective of passive judicial situations, that is, when a community is required to vacate a certain area. How to construct a procedural model that respects the procedural guarantees for a community that will have its legal assets directly affected? The Courts have so far responded to such demands by using traditional mechanisms, by the narrow and limited bias of proceduralism. The scope of this work is to demonstrate how limited this vision has been and then to make proposals so that the procedural instrument is aligned at the same level as the object that underlies it.
\end{abstract}

KEY WORDS: land conflicts - passive collective litigation - structural procedure

Author: Sabrina Nasser de Carvalho. The right of defense in land conflicts. Pages: 407. Doctorate. Faculty of Law, University of São Paulo, São Paulo, july, 2018. 



\section{SINTESI}

I conflitti territoriali, nonostante siano presenti da sempre nella storia dell'umanità, attualmente ricevono ampia attenzione da tutti i Poteri, data la dimensione del loro impatto nell'ambiente rurale e urbano, compresa la disseminazione della violenza. Le soluzioni comprendono azioni su diverse fronti ma, indubitabilmente includono politiche pubbliche che contribuiscano alla distribuzione equa e giusta di terreni e abitazioni. Quando i conflitti diventano controversie e sfociano nel sistema giudiziario, ci si accorge della difficoltà del sistema nel trattamento dello scontro con le sue particolarità inerenti, in specie riguardo l'aspettativa in riferimento a una decisione giusta e che il processo raggiunga scopi di altri ambiti, ovvero la pacificazione sociale. Al fine di copnseguire questo obiettivo, si fa assegnamento sul procedimento affinché coinvolga tutti gli elementi che integrano e costituiscono il conflitto, nonché assecondando le complessità pertinenti a questa modalità di controversia. Le difficoltà si intensificano quando si analizza la controversia dal punto di vista delle situazioni giuridiche passive, cioè quando si richiede ad una collettività di liberare una determinata area. Come costruire una metodologia che rispetti le garanzie procedurali di una moltitudine che avrà il suo patrimonio legale direttamente colpito? Attualmente i Tribunali rispondono a tali istanze utilizzando mecanismi tradizionali con una visione ristretta e limitata della processualità individuale. Lo scopo di questo lavoro è dimostrare quanto sia limitato questo concetto e, ulteriormente, formulare proposte in modo che lo strumento procedurale sia proporzionato all'oggetto basilare.

PAROLE CHIAVE: conflitti territoriali - controversie collettive passive - processo strutturale

Autore: Sabrina Nasser de Carvalho. Il diritto alla difesa nei conflitti territoriali. Dottorato. Pagine: 407. Facoltà di Diritto. Universita di São Paulo. São Paulo, luglio, 2018. 



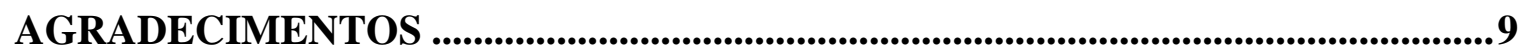

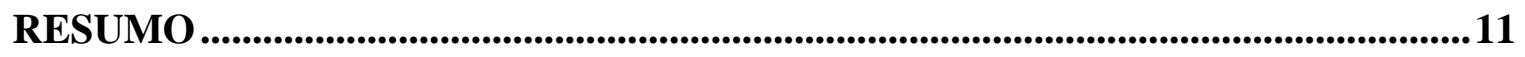

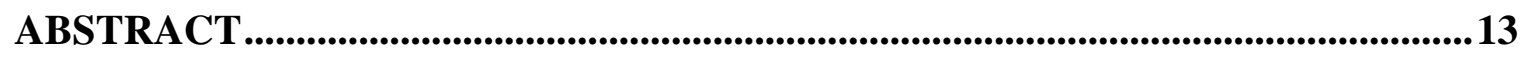

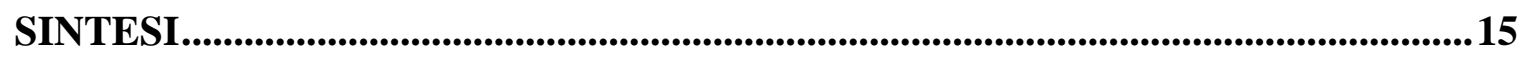

INTRODUÇÃO E METODOLOGIA....................................................................21

\section{CAPÍTULO 1 BREVES APONTAMENTOS SOBRE O RETRATO DOS}

CONFLITOS FUNDIÁRIOS NO BRASIL ...........................................................................29

1.1. CONFLITOS FUNDIÁRIOS NO BRASIL: UMA BREVE ABORDAGEM SOBRE OS ASPECTOS SOCIOLÓGICOS

1.2. MúltiPlas FACES dos CONFLITOS FUNDIÁRIOS: BREVE EXAME DOS ASPECTOS JURÍDICOS

1.3. CONFLITOS FUNDiÁRIOS NA AGENDA INSTITUCIONAL DOS TRÊS PODERES .........46

CAPÍTULO 2 ACESSO À JUSTIÇA: REFLEXÕES SOBRE O ACESSO À TERRA NA PERSPECTIVA DO DIREITO DE DEFESA ..................................................53

2.1. ACESSO À JUSTIÇA E SUA INTERFACE COM O ACESSO À TERRA.............................53

2.2. ACESSO À JUSTIÇA NA PERSPECTIVA DO DIREITO DE DEFESA................................64

CAPÍTULO 3 OBSTÁCULOS SOCIOECONÔMICOS AO DIREITO DE DEFESA NOS CONFLITOS FUNDIÁRIOS

3.1. OBSTÁCULOS SOCIOECONÔMICOS AO ACESSO À JUSTIÇA: LINHAS GERAIS ...........71

3.2. REFLEXOS DOS OBSTÁCULOS AO DIREITO DE DEFESA NOS CONFLITOS FUNDIÁRIOS

CAPÍTULO 4 CONFLITOS FUNDIÁRIOS E TUTELA POSSESSÓRIA.................95

4.1. PROCESSO, IDEOLOGIA E PROCEDIMENTOS ESPECIAIS ....................................95 
4.2. DiREITO E PROCESSO: A PARTICIPAÇÃO DO INSTRUMENTO NA CONSTRUÇÃO DA

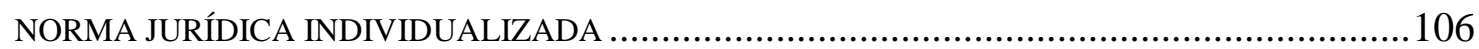

4.3. PROCEDIMENTO ESPECIAL POSSESSÓRIO: ANÁLISE CRÍTICA ...............................113

4.3.1. O Desafio Conceitual da Posse ................................................................... 113

4.3.2. Perspectiva crítica sobre o Procedimento Especial Possessório ...................121

4.3.2.1. Procedimento Especial das Ações Possessórias: tradição procedimental e reminiscências históricas

4.3.2.2 Reflexões sobre as normas que regem o litígio coletivo de posse no

Código de Processo Civil atual

4.3.2.3 A Ideologia Processual por trás dos Conflitos Possessórios Coletivos ...152

\section{CAPÍtulo 5 CONFLITOS PLURISSUBJETIVOS E OS OBSTÁCULOS PROCESSUAIS AO DIREITO DE DEFESA NOS CONFLITOS FUNDIÁRIOS.165}

5.1. RÉUS DESCONHECIDOS E A DESNECESSIDADE LEGAL DE QUALIFICÁ-LOS (ART.

319, PARÁGRAFO 3O, CPC): APONTAMENTOS E CONSIDERAÇÕES 165

5.2. CITAÇÃO NOS CONFLITOS PlURISSUBJETIVOS E AS DIFICULDADES PRÁTICAS PARA

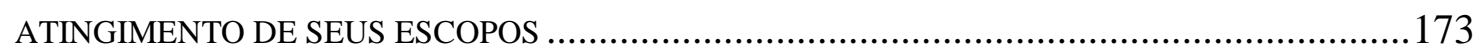

5.2.1 Citação e seu significado para o direito de defesa..........................................173

5.2.2 Citação de múltiplos réus nos conflitos fundiários.........................................179

5.2.2.1. Primeiro Ato: a tentativa de citação pessoal ............................................. 179

5.2.2.2. Segundo Ato: Citação por Edital ..............................................................183

5.2.3. Princípio da Publicidade e a sua incidência sobre o ato de citação..............188

5.2.4 O Papel do Curador Especial.

5.3. A COLETIVIDADE EM SITUAÇÃO JURÍDICA PASSIVA NOS CONFLITOS FUNDIÁRIOS: REFLEXÃO SOBRE MECANISMOS EFICIENTES PARA A GARANTIA DO DEVIDO PROCESSO LEGAL

5.3.1. Estrutura plurissubjetiva do conflito e a insuficiência dos institutos tradicionais .....

5.3.2 Seleção de Casos Plurisubjetivos no Polo Passivo: fenômenos sociológicos desafiando a ciência processual

5.3.2.1 Análise Processual dos "Rolezinhos" e das Ocupações nas Escolas no

Estado de São Paulo. 
5.3.2.2 Ações Plurissubjetivas e Direito de Defesa nos Conflitos Fundiários: propostas para um desenho procedimental mais garantista.

\section{CAPÍTULO 6 VIGAS PARA A CONSTRUÇÃO DE UM MODELO PROCESSUAL} PARA UMA DEFESA COLETIVA..........................................................................235

6.1. DEFENDANT CLASS ACTIONS: AÇÕES COLETIVAS PASSIVAS NORTE-AMERICANAS E

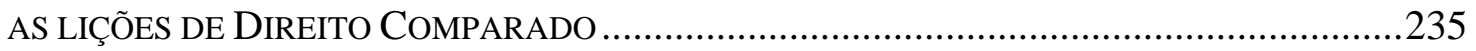

6.1.1. Aspectos introdutórios de Direito Comparado ...............................................235

6.1.2. Defendant Class Actions nos EUA: fundamentos teóricos e práticos para a compreensão do modelo paradigma.

6.2. Estágio atual do debate sobre as AÇões Coletivas Passivas no BRASIL

6.3. Defendant Class Actions e as AÇões Coletivas Passivas no Brasil: IDENTIFICAÇÃO DE PARÂMETROS PARA A CONSTRUÇÃO DE ALTERNATIVAS 268

6.4. LINHAS CONCLUSIVAS SOBRE OS INSTITUTOS QUE PERFAZEM AS AÇÕES Coletivas Passivas

\section{CAPÍTULO 7 INSTITUTOS REPRESENTATIVOS NOS CONFLITOS FUNDIÁRIOS PLURISUBJETIVOS PASSIVOS ....................................................285}

7.1. INSTITUTOS REPRESENTATIVOS NO SISTEMA PROCESSUAL ...............................285

7.2. Novo CPC E A PREVISÃO DE INTERVENÇÃO DO MinistÉRIO PÚBLICO E DA

DEFENSORIA PÚBLICA NOS LITÍGIOS COLETIVOS DE POSSE: A CONTROVÉRSIA DOUTRINÁRIA SOBRE A SUA NATUREZA JURÍDICA 291

7.2.1 Reflexões sobre as figuras processuais interventivas propostas . 303

7.2.2 Atuação da Defensoria Pública e do Ministério Público nos Litígios Coletivos de Posse: o direcionamento institucional. 315

7.3. ASSOCIAÇÕES E MOVIMENTOS SOCIAIS POR MORADIA: SEU PAPEL REPRESENTATIVO E ORGANIZACIONAL DAS COMUNIDADES NO PROCESSO 317

7.4. LEGITIMAÇÃO DE AGIR E REPRESENTATIVIDADE ADEQUADA À LUZ DOS LiTÍGIOS Coletivos De Posse 
CAPÍTULO 8 LITÍGIOS FUNDIÁRIOS E COLETIVIDADE NO POLO PASSIVO: PROPOSTA DE UM MODELO PARA O SEU CORRETO DIMENSIONAMENTO ..........................................................................................341

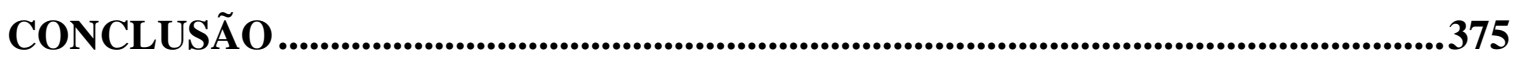

REFERÊNCIAS BIBLIOGRÁFICAS.................................................................379 


\section{INTRODUÇÃO E METODOLOGIA}

Os conflitos por terras acompanham a história do homem, independente da época, do território, do meio cultural, dos valores ou do contexto político. Por certo que a natureza, a intensidade, a dimensão e, principalmente, as razões que desencadeiam tais conflitos moldam-se de acordo com os interesses subjacentes ao meio social em que ocorrem, transmutando-se ao longo do tempo.

Na história do Brasil não foi diferente. A "descoberta” de nosso país pelo ocidente resultou numa grande invasão de terras alheias, com a exploração dos povos nativos em busca de expansão territorial para a conquista de novas riquezas. A divisão das terras em sesmarias marcou o início da apropriação particular do território brasileiro e tornou-se a gênese da desigualdade na distribuição fundiária, com reflexos permanentes no contexto atual.

Não é por outra razão que, no campo, a concentração fundiária forja-se como um dos obstáculos ao progresso da agricultura de base familiar e concorre para o êxodo da população mais vulnerável ao meio urbano. A configuração do retrato atual da política agrária brasileira faz emergir novos conflitos, que contrapõem, de um lado, os grandes proprietários e, de outro, aqueles que enxergam na ocupação de terras alheias uma forma de reivindicação política por espaços que entendem também lhe ser de direito.

A ubiquidade dos conflitos por terra faz destes conflitos ocorrência frequente no meio urbano. Os assentamentos irregulares que tomam conta das grandes cidades denotam que o déficit habitacional é, sem dúvida, um dos gargalos sociais mais críticos que o Estado enfrenta. A industrialização promoveu a migração em massa da população do campo para a cidade, que foi em busca de novas oportunidades e de novos meios de sobrevivência. $O$ resultado foi um processo de urbanização das cidades brasileiras sem planejamento e sem uma política habitacional efetiva aos novos trabalhadores, que viram nas ocupações dos espaços vazios a única forma de satisfazer a sua necessidade habitacional. Em consequência, as urbes brasileiras apresentam atualmente uma realidade de irregularidade espraiada, bastante distante das normativas urbanísticas e ambientais, e que avançam de forma desenfreada ante a escassez e a insuficiência das políticas públicas adotadas na área.

Se nas periferias dominam os loteamentos irregulares e as ocupações espontâneas, nos centros da cidade prevalecem as ocupações de imóveis vazios e ociosos, abandonados, muitas vezes, em razão da transferência do eixo econômico para outras regiões da cidade, 
atualmente mais valorizadas. Tais ocupações, quando realizadas de forma organizada por movimentos sociais, acabam por também expressar o descontentamento político deste segmento com o status quo urbanístico que impera nos centros urbanos, impulsionando ainda mais os conflitos de posse nas cidades brasileiras.

A situação é extremamente grave e, não raras vezes, os conflitos fundiários deságuam para a violência e até mesmo a morte dos envolvidos, tamanha é a tensão que os permeiam. Ademais, as contendas atinentes à posse e à propriedade estão inseridas em um contexto de forte oposição ideológica, o que contribuiu para um substancial acirramento do embate.

É neste cenário de agravamento do déficit habitacional e das condições de moradia, em que possuidores se confrontam com proprietários de áreas particulares ou com o próprio Poder Público, que o Poder Judiciário é chamado a intervir, aplicando as normas jurídicas às hipóteses fáticas que conformam referidos conflitos.

Diante das múltiplas faces dos conflitos fundiários no Brasil, exsurge-se a expectativa de que a atividade jurisdicional faça com eficiência a sua função de distribuir justiça, colimando, enfim, os escopos jurídico, social e político do processo. Mas o caminho para tanto não se mostra tão retilíneo, vez que a estrutura sociológica do conflito fundiário reproduzida no litígio judicial é extremamente complexa, especialmente ao considerar o exercício jurisdicional da população vulnerável que, regra geral, ocupa o polo passivo da lide e enfrenta sérios obstáculos para acessar o Poder Judiciário e para gozar das garantias fundamentais do devido processo legal.

Estes obstáculos vão exigir do Direito Processual respostas satisfatórias para que o direito substancial seja corretamente aplicado e para que os escopos social e político sejam efetivamente atingidos, já que a tensão e a contraposição ideológica que caracterizam esses conflitos também serão transpostas para a seara jurisdicional.

Nesse sentido, propõe-se investigar os desafios colocados por esta natureza de litígio ao Direito Processual, de modo a verificar como esta ciência pode contribuir para responder com eficiência e efetividade a necessidade que emerge do seio social.

Para tanto, inicialmente, é necessário identificar os obstáculos ao acesso à justiça enfrentados pelos jurisdicionados que figuram como réus em ações possessórias e reivindicatórias.

Apesar da abordagem do acesso à justiça sob seu prisma constitucional, conforme ditado pelos princípios e garantias do Estado Democrático de Direito, o estudo será devidamente delimitado sob a perspectiva do direito de defesa e pela análise das garantias 
processuais daqueles que são demandados em uma ação que tem como lide subjacente um conflito fundiário.

Os conflitos fundiários caracterizam-se pela disputa de posse ou de propriedade de um imóvel urbano ou rural, envolvendo pessoas de baixa renda ou grupos sociais vulneráveis.

Eis, então, a primeira barreira ao exercício do direito de defesa deste grupo social e, em última análise, para o acesso à justiça dos réus: trata-se de indivíduos de baixa renda, portanto, de poucos recursos para acessar os bens sociais. Há, inegavelmente, uma relação direta de causa e efeito entre a pobreza e o exercício jurisdicional pelo cidadão que figura como réu nas ações que versam sobre os conflitos fundiários, o que se pretende aprofundar no presente estudo.

Esse obstáculo econômico já foi objeto de estudo empírico por Garth e Cappelletti na década de 1970, quando então os autores inseriram-no como representativo da primeira onda renovatória de acesso à justiça. Portanto, não se trata de assunto novo para a doutrina, tampouco para o Poder Público, responsável por efetivar as políticas públicas que visam a infirmar e elidir os entraves socioeconômicos para a satisfação do acesso ao sistema de justiça aos mais pobres. De todo modo, mesmo depois de quase quarenta anos do Projeto de Florence, os países, inclusive os ditos desenvolvidos, ainda enfrentam extrema dificuldade para superar esta primeira onda renovatória, seja pelo razoável impacto que ainda causa, seja pela dificuldade de implementação de soluções definitivas, razão pela qual o assunto merece ser revisitado.

As fragilidades socioeconômicas ganham ainda mais cores quando contrastadas com as características da parte contrária, geralmente litigantes habituais e de alto poderio econômico e político: os proprietários particulares ou o Estado. Estes, regra geral, se utilizam das ações possessórias para a remoção desta coletividade ocupante, portanto, tendem a figurar como sujeitos que provocam o Poder Judiciário em busca de sua pretensão. Por esta razão, este trabalho irá abordar aspectos atinentes à tutela possessória, que vão desde institutos milenares até as alterações recentes, por ocasião do Código de Processo Civil de 2015. O escopo é analisar como estes institutos lidam com litígios que envolvem valores tão plurais e de largo interesse social, como os conflitos fundiários.

Mas não é só. A complexidade da espécie dos litígios em debate transcende a ordem socioeconômica para alcançar também o elemento subjetivo da lide: como outrora mencionado, trata-se de conflito multitudinário, ao menos de um dos lados do litígio, 
considerando que a ação é proposta contra o grupo social hipossuficiente que exerce a posse na área sub judice.

Surgem, assim, os obstáculos inerentes aos conflitos multitudinários, sendo que o primeiro deles revela-se na dificuldade de se integrar à lide todos aqueles que terão seu patrimônio jurídico atingido. Se analisarmos as áreas que constituem assentamentos irregulares na cidade de São Paulo, por exemplo, podemos verificar que algumas delas são constituídas de centenas ou até milhares de possuidores, com alta transição de moradores, seja em razão de novas ocupações, seja em razão do comércio informal de casas, barracos e terrenos nestas áreas. Considerando que a lide irá atingir o patrimônio jurídico de todos os ocupantes, vez que o processo vai decidir se tais indivíduos irão ser removidos da área que ocupam e onde exercem o seu direito à moradia, todos eles devem (ou deveriam) figurar como litisconsortes necessários e ser integrados à lide, sob pena de nulidade ou ineficácia da decisão, a depender do pedido formulado. Ao menos, esta é a regra sob a perspectiva da processualística individual.

Diante desse panorama, indaga-se: qual instrumento processual se mostra eficaz para resguardar as garantias processuais constitucionais dos ocupantes e, ao mesmo tempo, respeitar a duração razoável do processo e a observância da garantia da inafastabilidade da jurisdição que também o autor é titular? Como delinear um procedimento que consiga dimensionar as complexidades inerentes a esta espécie de litígio, que, inclusive, resvala em questões de interesse público?

A legislação processual vigente apresenta uma solução para o caso, regulamentada no artigo 554, parágrafos $1^{\circ}$ e $2^{\circ}$ do Código de Processo Civil, inserta na parte geral das ações possessórias: no caso de conflito possessório em que figure um grande número de pessoas com polo passivo, deve ser realizada a tentativa de citação pessoal dos possuidores por uma única vez na área, seguindo-se da citação por edital dos demais que não forem encontrados.

Trata-se de dispositivo que foi alvo de discussão e tensão entre grupos ideológicos distintos na Câmara dos Deputados no momento da aprovação do Código de Processo Civil de 2.015 (Lei 13.105/15), opondo a bancada ruralista de um lado, e, de outro, a bancada popular, que encampava os pleitos dos movimentos sociais de moradia. Ao final, chegouse a um denominador comum: a imbricação entre a citação pessoal, mas apenas uma única vez, seguida da citação ficta, por edital.

Com a presente pesquisa, pretende-se analisar a solução prevista pela recente legislação processual, notadamente se essa se revela suficiente e eficiente para o respeito 
do acesso à justiça dos requeridos, ou seja, para o exercício pleno de todas as garantias constitucionais e fundamentais inerentes ao direito de defesa. Em consequência, pretendese verificar a constitucionalidade da autorização da citação apenas a parte dos possuidores, bem como da citação ficta à luz das garantias do devido processo legal constitucional, buscando, em contrapartida, meios de compensação do afastamento de garantias, a princípio, individuais.

O Novo Código de Processo Civil previu, ainda, a intimação do Ministério Público e da Defensoria Pública nas ações possessórias em que houver um grande número de pessoas no polo passivo, também nos termos do artigo 554, parágrafo $1^{\circ}$ do Código de Processo Civil. Segundo o mencionado dispositivo, a intimação da Defensoria Pública deve ocorrer apenas nos casos de hipossuficientes do ponto de vista econômico.

A inclusão destas intervenções no texto legal também foi fruto de pressão popular feita pelos movimentos sociais de moradia na Câmara dos Deputados quando da discussão do Projeto de Lei do NCPC. Entendiam os movimentos sociais que a participação destas instituições iria infirmar ou até eliminar o que eles reputavam como arbitrariedades cometidas nos processos de reintegração de posse das áreas ocupadas por um grupo de pessoas. Mas o dispositivo é bastante genérico e nada menciona sobre a qualidade que tais instituições intervêm no processo, gerando dúvidas quanto aos seus poderes processuais, quanto às matérias que podem opor em juízo e ainda sobre a suposta parcialidade de suas manifestações em favor do polo passivo multitudinário. Diante de todas estas indagações, faz-se essencialmente importante perquirir acerca da natureza jurídica da intervenção do Ministério Público e da Defensoria Pública para que se possam alcançar respostas acertadas às indagações supracitadas.

Em suma, almeja-se, por meio deste trabalho, revelar em que medida o Direito Processual pode ser compreendido e interpretado para proporcionar maior acesso à justiça àqueles que figuram no polo passivo da lide multitudinária que versa sobre conflitos fundiários. E, ademais, como o instrumento pode se moldar para acompanhar as idiossincrasias desta modalidade de conflito, mantendo-se sempre justaposto à realidade apresentada pelo direito material. De forma mais clara, busca-se responder à seguinte questão: qual o modelo processual justo (acesso à ordem jurídica justa) para a solução de conflitos fundiários, especificadamente quando a coletividade está no polo passivo?

Desta forma, a pesquisa contemplará a análise acerca da importância do papel do Processo Civil para a construção dos fatos e do substrato jurídico essencial ao processo hermenêutico, resgatando a importância da ciência processual para concorrer com a 
formação da norma jurídica individualizada, afastando-se, deste modo, da concepção da visão clássica de acessoriedade e adjetividade das normas processuais quando comparadas com o direito material. Portanto, pretende-se garantir uma abordagem que envolva a interrelação entre direito e processo, partindo-se da doutrina contemporânea que não compreende o processo como um instrumento neutro ou indiferente à realidade social, mas, ao contrário, que constitui um importante fator de desenvolvimento para a aplicação do direito substancial.

Para uma abordagem sistematizada sobre o objeto desta pesquisa, faz-se necessário traçar os passos, delimitar os procedimentos e apresentar a metodologia que será utilizada para atingir o objetivo proposto.

Inicialmente, os esforços serão concentrados na busca da identificação das barreiras ao acesso à justiça nesta modalidade de conflitos. Neste momento inicial, propõese a existência de duas naturezas distintas de obstáculos: sociológica e processual. Os primeiros referem-se aos aspectos econômicos, sociais, culturais e psicológicos relacionados aos cidadãos que vivem nestes assentamentos irregulares, os quais interferem diretamente na garantia em pauta, infirmando a sua efetividade. Os demais se inserem no espectro de natureza instrumental, ou seja, relacionam-se à estrutura processual dos conflitos, que, em razão de sua conformação subjetiva, acabam por esbarrar nas limitações inerentes às normas processuais. Questiona-se, como dito, as limitações do procedimento especial possessório como meio primordial para lidar com as complexidades inerentes ao conflito. Neste mesmo sentido, abordam-se as insuficiências dos meios clássicos, como a citação por edital e o litisconsórcio, para garantir o contraditório de uma multidão que deve figurar no polo passivo, o que se mostra, cada vez mais, característica dos novos litígios que apontam no Poder Judiciário.

Delimitadas as barreiras, buscar-se-á discutir em que medida elas resvalam na garantia do acesso à justiça na perspectiva do direito de defesa, para que seja possível, então, fazer propostas para que o método se sensibilize frente às necessidades e anseios sociais.

No caso dos obstáculos socioeconômicos, em razão de haver vasta literatura e pesquisas sobre o assunto, a discussão encontrará respaldo em dados secundários, ou seja, aqueles já colhidos em razão de pesquisas empíricas anteriormente realizadas. Com base nestes dados, serão discutidos os impactos sentidos no acesso à justiça dos réus nos conflitos fundiários. Mesmo não se tratando de uma abordagem original, entendemos ser imprescindível inserir no debate tais obstáculos, considerando que a discussão acerca do 
acesso à justiça não pode prescindir de tal perspectiva. Em primeiro lugar, porque tais obstáculos seguem como os principais limitadores desta importante garantia constitucional para as partes no litígio. E, ainda, porque nem sempre se mostram transparentes, identificáveis à primeira vista, já que não se revestem de atos formais e concretos, como ocorre com os obstáculos processuais. Assim, tais barreiras podem estar conjugadas com obstáculos de outras naturezas, e, em muitos casos, imbricam-se de tal forma que não se faz possível identificar aquele que realmente foi o responsável por limitar o acesso à justiça ao demandado. De todo modo, é importante que tais obstáculos sejam revisitados e novamente discutidos para ressaltar que não passam desapercebidos aos olhos desta pesquisa.

Adentra-se, posteriormente, nos obstáculos processuais. Em um primeiro momento, faz-se necessário trazer à baila as questões teóricas para pontuar os requisitos formais sobre os quais subjazem os institutos processuais e definir seus conceitos. Portanto, pelo filtro das normas que regulamentam tais institutos e da doutrina, o aprofundamento se dará com fulcro na dogmática jurídica, de modo a compreender as bases, inclusive históricas, em que se assenta o pressuposto normativo e axiológico daquela regra ou princípio posto. Ter-se-á, assim, o paradigma atualmente vigente, sobre o qual se pretende lançar um olhar crítico, que será feito por meio de outras perspectivas, não eminentemente dogmáticas. Em suma, esta fase será dedicada ao estabelecimento de uma plataforma teórica sobre a qual a pesquisa se sustenta.

Justamente na linha de uma abordagem mais crítica, a escolha da metodologia deve compreender instrumentos hábeis à análise da contingência fática que molda tais conflitos. A proposta é determinar com maior precisão possível os pressupostos de fato que condicionam a adoção do dogma em questão, a fim de perquirir se há uma relação dialógica e estreita entre a dogmática e a realidade. Por esta razão, mesmo na discussão dos obstáculos processuais, serão utilizados dados e pesquisas empíricas realizadas em outros trabalhos, acerca da judicialização destes conflitos, com o objetivo de analisar como os tribunais têm interpretado as normas processuais que servem de veículo ao direito substancial. Da mesma forma, com vistas a uma abordagem crítica, utiliza-se de uma literatura multidisciplinar, de modo que o fenômeno processual seja examinado por diversas perspectivas, sempre buscando um foco mais próximo da realidade, para que seja possível, então, possibilitar propostas efetivamente conexas com as necessidades sociais. 


\section{CONCLUSÃO}

Feita a sistematização das propostas no capítulo anterior, passamos, em linha de conclusão, a declinar as últimas palavras acerca da contribuição do Direito Processual sobre a melhor forma de lidar com os litígios fundiários, seja para se alcançar uma decisão eminentemente justa, seja para a concretização dos demais escopos do processo, entre eles o escopo social, com a expectativa de que o processo possa efetivamente contribuir para a pacificação social, ou, ao menos, concorrer para a redução da violência, a qual, infelizmente, é bastante comum neste tipo de conflito.

Do início ao fim deste trabalho buscou-se demonstrar as complexidades que permeiam os conflitos no campo e no meio urbano. O reconhecimento da visão estritamente reducionista do litígio, portanto, de que se trata apenas de um embate entre proprietário e uma multidão de ocupantes, é o primeiro passo. Neste sentido, a premissa para a revisão do modelo procedimental mais adequado passa pela análise de outras lentes, mais focadas em retratar com profundidade os fatores envolvidos e que acabam por revelar inúmeras questões de interesse público, com inegáveis reflexos sociais, econômicos e políticos.

Este contexto, de nuances de diversas naturezas, não é menosprezado pelo ordenamento jurídico que regulamenta o Direito Material. Se analisarmos as normas jurídicas que perfazem o Direito Urbanístico e o Direito Agrário, iremos verificar consequências jurídicas de diversas ordens que recaem sobre os assentamentos irregulares, inclusive com deveres e responsabilidades de múltiplos sujeitos. Este contexto jurídico se contrasta flagrantemente com a insistência dos tribunais de aplicação do espectro normativo estritamente codicista, agravado por uma interpretação arraigada sobre os pilares individualistas e liberais. O resultado é a manutenção do direito à propriedade no topo da hierarquia dos bens jurídicos.

Analisar o litígio fundiário com a densidade e a sensibilidade normativa pertinente irá exigir do Direito Processual mudança brusca em sua estrutura. Sem dúvida nenhuma, o embate polarizado, limitado à solução tudo ou nada (lícito ou ilícito), com restrições estruturais rígidas, que apenas permitem a subsunção legalista do fato à norma, demandará uma estrutura processual simplista, pautado em um devido processo legal formal, satisfazendo-se apenas com a contraposição dialética eminentemente escrita. Por outro lado, uma leitura mais apurada dos ingredientes que concorrem para a formação do conflito e das respostas a estes elementos exigirá um método de solução de conflitos que também acompanhe estas complexidades e se amolde para integrar os sujeitos que 
necessitam participar do diálogo, a fim de que haja condições para se alcançar uma decisão mais justa.

$\mathrm{Na}$ verdade, o presente trabalho debruçou-se sobre uma modalidade de conflito fundiário com um agravante adicional: analisamos os litígios em que a coletividade está no polo passivo da lide. Assim, não obstante toda a complexidade que permeia um litígio que discute o direito à moradia e à terra de uma comunidade, acresce-se o fato de que o Direito Processual pátrio não dispõe, ao menos expressamente, de um procedimento adequado para lidar com a multiplicidade de sujeitos no polo passivo da lide, que terão, necessariamente, o seu patrimônio jurídico atingido pela decisão a ser proferida.

Após uma densa reflexão, concluímos que a processualística individual que ora é aplicada pelos tribunais não é suficiente para respeitar as garantias constitucionais mais basilares nesta espécie de conflito. O gozo pela perspectiva individual do devido processo legal pode, a princípio, transparecer uma maior proteção ao jurisdicionado, mas, após uma análise mais acurada, é possível concluir que ela é incapaz de produzir efeitos concretos diante do largo espectro do elemento subjetivo, sendo que, a partir de determinado momento, torna-se apenas uma garantia formal.

A proposta, portanto, buscou no Direito Processual Coletivo uma saída mais efetiva a esta modelagem de litígio. Institutos como legitimidade preconizada no modelo representativo, coisa julgada ultra partes, maior poder do órgão julgador, flexibilidade procedimental e mecanismos democráticos, como audiências públicas e amicus curiae, concorrem para satisfazer a complexidade objetiva e subjetiva e, assim, deixar o procedimento mais justo e mais consentâneo com a realidade.

Esta proposta foi extraída da normativa posta. Desta forma, ainda que não descrita expressamente pela legislação processual, pode-se afirmar que o Direito Processual, seja pelas reformas vindas com o $\mathrm{CPC} / 15$, que, malgrado não ter adentrado no modelo instrumental coletivo, tornou o procedimento mais permeável às mudanças direcionadas pelo objeto subjacente à lide, seja também pelo nosso microssistema processual (Lei 7.347/85 e 8.078/90), que, se por um lado não rege especificamente as situações jurídicas passivas coletivas, por outro não apresenta empecilho para a sua aplicação às situações jurídicas passivas.

Esta conclusão nos leva a reconhecer a possibilidade das ações coletivas passivas lege lata. É certo que a procedimentalização deste modelo de litígio não parece ser tão retilínea. Há, sem dúvida alguma, várias dificuldades que necessitam de um estudo amplo, inclusive de todas as hipóteses que podem desencadear a judicialização deste tipo de 
conflito. As ações coletivas trazem ínsitos efeitos econômicos, políticos e sociais que dificultam um molde único a todas elas. De todo modo, é possível e recomendável, para se garantir maior segurança jurídica, que a questão seja objeto de regulamentação legislativa, ao menos das premissas básicas das ações coletivas passivas.

No que pertine aos litígios fundiários, concluímos que a legitimação coletiva passiva deve recair, preferencialmente, sobre os líderes dos movimentos sociais e do presidente da associação, caso a comunidade tenha este tipo de organização social. Em caso negativo, a legitimação pode recair sobre um dos ocupantes, que tenha potencialidade de representar ideologicamente o sujeito coletivo, portanto, que consiga desempenhar a função de porta-voz do grupo.

De todo modo, o legitimado coletivo passivo deve ter a sua representação analisada casuisticamente pelo órgão julgador, a fim de aferir se ela é efetiva, se há homogeneidade no grupo e este pode ser um legitimado ideológico. Caso não haja potencialidade técnica, a Defensoria Pública pode colmatar esta lacuna, vez que é responsável pela representação judicial gratuita aos vulneráveis.

Ainda assim, após a fase citatória, caso não haja a intervenção de um ocupante ou, se aqueles que intervieram não se mostraram porta-voz da comunidade, a Defensoria Pública ou o Ministério Público passam a atuar como legitimados coletivos passivos em nome da coletividade. Frise-se que a defesa neste trabalho foi por uma legitimação coletiva subsidiária destes dois entes, privilegiando-se e colocando como protagonistas os integrantes da classe. A experiência e idoneidade destes dois órgãos públicos garantem a presunção, ainda que relativa, de representantes adequados, o que, de forma alguma, os retira a possibilidade de fazer requerimentos e requerer diligências que se mostrem necessárias para respaldar a sua adequada atuação, principalmente pertinentes à mobilização da coletividade para que também participe da elaboração da defesa coletiva.

Assim, procuramos aproximar o procedimento à realidade dos conflitos fundiários, de modo a buscar um maior equilíbrio de armas entre as partes, mormente diante da vulnerabilidade da multidão que figura no polo passivo e que não consegue exercer, pessoalmente, a sua defesa. Buscamos, também, institutos mais democráticos, participativos, garantistas, que propiciem o diálogo para a solução consensual do conflito, ou, se não for possível, um provimento jurisdicional que consiga se mostrar sensível aos nuances do direito material em discussão. Não descuramos que o procedimento, por si só, não garante uma decisão substancialmente justa, mas, partindo-se da premissa da natureza 
do processo integrativo, não se pode negar que o caminho a se percorrer pode contribuir sobremaneira para que a justiça se materialize. 


\section{REFERÊNCIAS BIBLIOGRÁFICAS}

ABRAMOVAY, Pedro. Liminar que proíbe "rolezinho" assegura "direito à segregação". Folha de São Paulo. São Paulo. Publicado 14/01/2014. Disponível em http://www1.folha.uol.com.br/cotidiano/2014/01/1397333-opiniao-liminar-queproibe-rolezinho-assegura-direito-a-segregacao.shtml.

ACCA, Thiago dos Santos. A (des)segregação urbana por meio do Direito: o Poder Judiciário, as políticas públicas e o caso da ponte Estaiadinha. In: As Múltiplas Faces do Conflito Fundiário no Brasil. Análise CPJA/Direito Gvol. Maio de 2014.

ALEXY, Robert. Teoria dos Direitos Fundamentais. Trad. Virgílio Afonso da Silva. São Paulo: Malheiros, 2008.

ALFONSIN, Jacques Távora. A Força Normativa das Necessidades frente ao Direito de Propriedade: Apontamento em torno dos efeitos jurídicos gerados por ocupações massivas de terra urbana e rural. In: STROZAKE, Juvelino José (Org.). Questões Agrárias. Julgados comentados e Pareceres. São Paulo: Método, 2002.

. O Acesso à Terra como conteúdo de direitos humanos fundamentais à alimentação e à moradia. Porto Alegre: Sergio Fabris Editor, 2003.

Os Conflitos Possessórios e o Judiciário. Três reducionismos processuais de solução. In: STROZAKE, Juvelino José (Coord.). O Direito Agrário em Debate. Porto Alegre: Livraria do Advogado, 1998.

ALMEIDA FILHO, Carlos Alberto Souza de. MAIA, Maurílio Casas. O Estado defensor e sua legitimidade para os pedidos de suspensão de liminar de segurança e tutela antecipada. In: Revista de Processo Civil. São Paulo: Revista dos Tribunais. Ano 40. vol. 239. Janeiro/15.

ALVIM, Teresa Arruda. A posição dos sócios e associados em relação a ações movidas contra as sociedades e associações de que façam parte. In: DIDIER Jr., Fredie; WAMBIER, Teresa Arruda Alvim (Coord.). Aspectos Polêmicos e Atuais sobre os Terceiros no Processo Civil e assuntos afins. São Paulo: Revista dos Tribunais, 2004.

. Manual de Direito Processual Civil. São Paulo: Revista dos Tribunais, 2010.

. O Direito Processual de estar em Juízo. In: Coleção de Estudos de Direito de Processo Enrico Tullio Liebman. São Paulo: Revista dos Tribunais, 1996.

ANCHETA, Angelo N. Defendant Class Actions and Federal Civil Rights Litigation. UCLA Law Review, 33, 283.

ANDRADE, Adriano de Azevedo. O Fundamento da Proteção Possessória. BH: Universidade de Minas Gerais, 1964.

APPIO, Eduardo. Direito das Minorias. São Paulo: Revista dos Tribunais, 2009. 
ARAÚJO, Fabio Caldas. Posse. Rio de Janeiro; Editora Forense, 2007.

ARAÚJO, José Aurélio de. O Litígio Coletivo da Posse dos Artigos 554 e 565 do Novo CPC e a Natureza da Atuação da Defensoria Pública. In: SOUSA, José Augusto Garcia de (Coord.). Repercussões do Novo CPC. Salvador: JusPodiVm, out/2015.

ARENHART, Sérgio Cruz. A Tutela de Interesses Individuais: Para além da proteção de interesses individuais homogêneos. São Paulo: Revista dos Tribunais, 2013.

Decisões Estruturantes no Direito Processual Civil Brasileiro. In: Processos Coletivos. Revista Eletrônica. vol. 6, n. 4, jan.-abril de 2015. Disponível em http://www.processoscoletivos.com.br/index.php/68-volume-6-numero-4-trimestre01-10-2015-a-31-12-2015/1668-decisoes-estruturais-no-direito-processual-civilbrasileiro.

ARMELIN, Donaldo. Ação Civil Pública: legitimidade processual e legitimidade política. In: Processo Civil e Interesse Público: o processo como instrumento de defesa social. São Paulo: Revista dos Tribunais, 2003.

AROCA, Juan Montero. El Processo Civil llamado "social" como instrumento de "justicia" autoritária. In: AROCA, Juan Montero (Coord.). Proceso Civil e Ideologia: un prefacio, una sentencia, dos cartas y quince ensayos. Valencia: Tirant Lo Blanch, 2006.

AURELLI, Arlete Inês. Ações Possessórias. In: BUENO, Cassio Scarpinella (Coord.). Comentários ao Código de Processo Civil. São Paulo: Saraiva, 2017.

AVRITZER, Leonardo; MARONA. Marjorie; GOMES, Lilian C. B. (Org.). Cartografia da Justiça no Brasil: uma análise a partir de atores e territórios. São Paulo: Saraiva, 2014.

BAPTISTA, Bárbara Gomes Lupetti. Os Rituais Judiciários e o Princípio da Oralidade: construção da verdade no Processo Civil Brasileiro. Porto Alegre: Sergio Antonio Fabris, 2008.

BATISTA, Lia Carolina. Assistência simples no Direito Processual civil. Dissertação de Mestrado apresentada à Faculdade de Direito da Universidade de São Paulo, 2012.

BALDEZ, Miguel Lanzellotti. Sobre o papel do direito na sociedade capitalista. Ocupações coletivas: direito insurgente. Disponível em http://www.forumjustica.com.br/wpcontent/uploads/2013/02/24135779-Miguel Lanzellotti-Baldez-Sobre-o-papel-dodireito-na-sociedade-capitalista-direito-insurgente.pdf.

BANDEIRA DE MELO, Celso Antônio. Novos Aspectos da Função Social da Propriedade no Direito Público. Revista de Direito Público, n. 84, São Paulo: Editora Revista dos Tribunais, 1987.

BARBOSA, Rafael Vinheiro Monteiro. MAIA, Maurílio Casas. Isonomia Dinâmica e Vulnerabilidade no Direito Processual Civil. In: Revista de Direito Processual. RT. Ano 39. vol. 30, abril de 2014. 
BARROS MONTEIRO, Washington de; MALUF, Carlos Alberto Dabus. Curso de Direito Civil. 39. ed. São Paulo: Saraiva, 2009.BARROSO, Luís Roberto. O Direito Constitucional e a efetividade de suas normas: limites e possibilidades da Constituição Brasileira. Rio de Janeiro: Renovar, 2006.

BECKER, Howard S. A Epistemologia da Pesquisa Qualitativa. In: Revista de Estudos Empíricos em Direito, vol. I, jul.2014.

BECKER, L. A. Contratos Bancários: execuções especiais. São Paulo: Malheiros: 2002.

- Qual é o jogo do processo? Curitiba: Sergio Fabris, 2012.

. Processo e Preconceito. In: Elementos para uma Teoria Crítica do Processo. Porto Alegre: Sergio Fabris, 2002.

BEDAQUE, José Roberto dos Santos. Direito e Processo: influência do Direito Material sobre o processo. São Paulo: Malheiros, 2009.

Tutela Cautelar e Tutela Antecipada: tutelas sumárias e de urgência (tentativa de sistematização). $5^{\text {a }}$ edição. São Paulo: Malheiros, 2009.

BEGA, Carolina Brambila. Curadoria Especial: Tutela da Vulnerabilidade Processual. Análise da efetividade dessa atuação. Tese apresentada à Faculdade de Direito da Universidade de São Paulo, sob orientação do Professor Associado Rodolfo de Camargo Mancuso. São Paulo. 2012.

BENEVIDES, Maria Victoria. Direito, Cidadania e Participação. São Paulo: T.A. Queiroz. 1981.

BENTES, Fernando R. N. M.; HOFFMANN, Florian F. A litigância judicial dos direitos sociais no Brasil: uma abordagem empírica. In: SOUZA NETO, Cláudio Pereira de; SARMENTO, Daniel (coords). Direitos Sociais: fundamentos, judicialização e direitos sociais em espécie. Rio de Janeiro: Lumen Juris, 2008.

BENTE, Richard Hugh. Regularização Fundiária de Interesse Social no Estado de São Paulo: uma análise dos programas Pró-Lar e Cidade Legal nos Município do Vale do Paraíba. Tese (Doutorado). Escola de Engenharia de São Carlos para a obtenção de título de doutor em Arquitetura e Urbanismo. Universidade de São Paulo, 2010.

BESSI, Bruna. Manifestações Culturais Espontâneas Transformam a Cidade de São Paulo. G1. São Paulo. Publicado 19/05/2013. Disponível em http://delas.ig.com.br/casa/arquitetura/2013-05-19/manifestacoes-culturaisespontaneas-transformam-a-cidade-de-sao-paulo.html.

BONDUKI, Nabil. Origens da Habitação Social no Brasil: Arquitetura, Lei do Inquilinato e Difusão da Casa Própria. São Paulo: Estação Liberdade, 2011.

BONÍCIO, Marcelo José Magalhães. Princípios do Processo Civil no Novo Código de Processo Civil. São Paulo: Saraiva, 2016. 
. Proporcionalidade e Processo: A Garantia Constitucional da Proporcionalidade, a Legitimação do Processo Civil e o Controle das Decisões Judiciais. São Paulo: Atlas, 2006

BONÍCIO, Marcelo José Magalhães; SICA, Heitor Vitor Mendonça. In: MENDES, Aluísio Gonçalves de Castro; WAMBIER, Teresa Arruda Alvim. O Processo em perspectiva. Jornadas Brasileiras de Direito Processual. São Paulo: Revista dos Tribunais, 2013.

BOULOS, Guilherme. Por que ocupamos? Uma introdução à luta dos sem-teto. São Paulo: Autonomia Literária, 2015.

BOURDIEU, Pierre. La noblesse de lÉtat. Paris: Minuit, 1989.

BRAGA, Luiz Guilherme. A posse de ano e dia no Direito Hispânico Medieval. In: Boletim de Direito de Coimbra Disponível em https://www.uc.pt/fduc/corpo_docente/galeria_retratos/braga_cruz/pdf/doutrina_bc _vol_XXV_1949.pdf.

BUENO, Cassio Scarpinella. Amicus Curiae: Uma Homenagem a Athos Gusmão Carneiro. In: DIDIER, Fredie et al (Coord.). O terceiro no Processo Civil brasileiro e assuntos correlatos: estudos em Homenagem ao Professor Gusmão Carneiro. São Paulo: RT, 2010 .

Processo Civil de Interesse Público: uma proposta de sistematização. In: SALLES, Carlos Alberto de (Org.). Processo Civil de Interesse Público: o processo como instrumento de defesa social. São Paulo: Revista dos Tribunais, 2003.

CABRAL, Antonio do Passo. A causa de pedir nas ações coletivas. In: Tutela Jurisdicional Coletiva. Salvador: JuspodiVm, 2009.

. A escolha da causa-piloto nos incidentes de resolução de processos repetitivos. In: Revista de Processo. vol. 231. Maio de 2014.

CABRAL, Antonio do Passo; CRAMER, Ronaldo. Comentários ao art. 982. In: Comentários ao novo Código de Processo Civil. Rio de Janeiro: Forense, 2015.

CALAMANDREI, Piero. O processo como jogo. Direito Processual Civil. vol. 3. Trad. Luiz Avezia; Sandra Drina Fernandez Barbery. Campinas: Bookseller. 1999.

Proceso y Democracia. Trad. Hector Fix Zamudio. Buenos Aires: Ediciones Juridicas Europa-America, 1960.

CALMON DE PASSOS, José Joaquim. Função Social do Processo. Disponível em https://jus.com.br/artigos/3198/funcao-social-do-processo.

. Instrumentalidade do Processo e Devido Processo Legal. In: Revista de Diálogo Jurídico. Ano I, vol. I, abril de 2001, Salvador/BA. 
Teoria Geral dos Procedimentos Especiais. In: Artigos e Ensaios. Salvador: Jus PodiVm. vol. 2, 2016.

CAMBI, Eduardo. Neoconstitucionalismo e Neoprocessualismo: direitos fundamentais, políticas públicas e protagonismo judiciário. São Paulo: Revista dos Tribunais, 2009.

CAMPILONGO, Celso Fernandes. Direito e Diferenciação Social. São Paulo: Saraiva, 2011.

CANOTILHO, Tópicos de um Curso de Mestrado sobre Direitos Fundamentais, procedimento, processo e organização. In: Boletim da Faculdade de Direito da Universidade de Coimbra. vol. LXVI, 1991.

CAPPELLETTI, Mauro; GARTH, Bryant. Acesso à Justiça. Trad. Ellen Gracie Northflet. São Paulo: Sérgio Antonio Fabris, 2002.

- Formações Sociais e interesses coletivos diante da justiça civil. In: Revista de Processo. São Paulo: RT, n. 5, pp. 128-159. Jan/mar. 1977.

Los Derechos Sociales de liberdad em la concepción de Piero Calamandrei. In: Processo, ideologia e sociedade. Buenos Aires: EJEA, 1974.

Os Métodos alternativos de solução dos conflitos no quadro do movimento universal do acesso à justiça. Trad. José Carlos Barbosa Moreira. In: Revista de Processo. São Paulo: 74(19):82-97, abri/jun. 1994.

Processo, Ideologias e Sociedade. vol. II. Porto Alegre: Sérgio Antonio Fabris, 2010.

CARMONA, Carlos Alberto. Considerações sobre a evolução conceitual do processo. In: Revista de Processo Civil. n. 57, ano 15, janeiro-março 1990.

CARNELUTTI, Francesco. Diritto e Processo. Napolis: Morano Editore, 1958.

CARVALHO, Cláudio Oliveira de; RODRIGUES, Raoni. O Novo Código de Processo Civil e as Ações Possessórias: Novas Perspectivas para os Conflitos Fundiários Coletivos? In: Revista de Direito da Cidade. vol. 07, n. 4. Rio de Janeiro, UERJ, 2015.CARVALHO, Eduardo Guimarães de. O Negócio da Terra. Rio de Janeiro: Editora UFRJ, 1991.

CARVALHO, Eusébio. Direito à Propriedade: do discurso à realidade. In: FARIAS, Cristiano Chaves de (Org.). Leituras Complementares de Direito Civil: O Direito Civil Constitucional em Concreto. Salvador: JuspodiVm, 2007.

CARVALHO, Sabrina Nasser. Judicialização dos Assentamentos Irregulares: reflexões necessárias. In: Revista Magister. Ano X, n. 58. Fev/mar. 2015.

. Processos Coletivos e Políticas Públicas. São Paulo: Contracorrente, 2016.

CARVALHO, Sabrina Nasser de; ZAMONER, Tatiana. Direito à Moradia e Áreas Ambientalmente Protegidas: a abordagem conciliatória como estratégia de ação no 
enfrentamento do conflito. In: Temas Aprofundados da Defensoria Pública. Salvador: JusPodiVm. vol. 2. 2014.

CASTELO, Juliana Justo Botelho. Litigância de Massa: ações coletivas e técnicas de agregação. Tese (Doutorado). Faculdade de Direito da Universidade São Paulo. São Paulo: Universidade de São Paulo, 2014.

CHASE, Oscar G. Direito, Cultura e ritual: Sistemas de resolução de conflitos no contexto da cultura comparada. São Paulo: Marcial Pons, 2014.

CHAYES, Abram. The role of the judge in public law litigation. Harvard Law Review, $\mathrm{n}$. 7, vol. 89, mai, 1976.

CHIOVENDA, Giuseppe. Instituciones de Derecho Procesal Civil. Tomo I. Madrid: Revista de Derecho Privado, 1954.

. Instituciones de Derecho Procesal Civil. vol. II. Madrid: Revista de Derecho Privado, 2005.

CINTRA, Antônio Carlos de Araújo; GRINOVER, Ada Pellegrini; DINAMARCO, Cândido Rangel. Teoria Geral do Processo. São Paulo: Malheiros, 2008.

COELHO, Maria da Silva Varela. A Extinção do Procedimento Especial nas Ações de Reintegração e de Manutenção de Posse: causa e consequências. In: Academia Brasileira de Direito Processual Civil. Disponível em http://www.abdpc.org.br/abdpc/artigos/MARINA\%20DA\%20SILVA\%20VAREL A\%20COELHO-\%20Vers\%C3\%A3o\%20final.pdf.

CORTIANO Jr., Eroulths. O discurso jurídico da propriedade e suas rupturas: uma análise do ensino do direito de propriedade. Rio de Janeiro: Editora Renovar, 2002.

COUTURE, Eduardo J. Fundamentos do Direito Processual Civil. Trad. Rubens Gomes de Sousa, São Paulo: Saraiva, 1946. . Introdução ao Estudo do Processo Civil: discursos, ensaios e conferências. Trad. de Hilomar Martins de Oliveira. Belo Horizonte: Líder, 2008.

COMOGLIO, Luigi Paolo. Direzione de processo e responsalità del iudice. In: Studio in onore di E. T. Liebman. vol. 1. Milano: Giuffrè, 1979.

COMOGLIO, Luigui Paolo; FERRI, Corrado; TARUFFO, Michele. Lezione sul Processo Civile. vol. 1. 5. ed. Bologna: II Mulino, 2011.

COMPARATO, Fábio Konder. Direitos e Deveres fundamentais em matéria de propriedade. In: STROZAKE, Juvelino José. (Org.). A Questão Agrária e a Justiça. São Paulo: Revista dos Tribunais, 2000.

CORREA, Mariza. Morte em Família. Rio de Janeiro: Graal. 1983. 
CORREIA, André de Luizi. A Citação no Direito Processual Civil Brasileiro. São Paulo: Revista dos Tribunais, 2001.

COSTA, Domingos Barroso da. GODOY, Arion Escorsin de. Defensoria precisa definir identidade para não se prender ao passado. In: Revista Conjur. Publicado em 21/07/2015. Disponível em https://www.conjur.com.br/2015-jul-21/tribunadefensoria-defensoria-definir-identidade-nao-prender-passado.

COSTA, Susana Henriques da; FRANCISCO, João Eberhardt. Uma hipótese de Defendant Class Actions no CPC? O papel do Ministério Público na Efetivação do Contraditório nas Demandas Possessórias propostas em face de pessoas desconhecidas. In: Revista de Processo. Ano 40, n. 250, dezembro de 2015.

COSTA, Susana Henriques da. O Controle judicial da representatividade adequada. In: SALLES, Carlos Alberto (Org.). As grandes transformações do processo civil brasileiro. São Paulo: Quartier Latin, 2009.

CRAMER, Ronaldo. In: CABRAL, Antônio do Passo. Comentários ao NCPC. São Paulo: Forense, 2016.

CREDIE, Ricardo Antônio Arcoverde. As ações de manutenção e imissão na posse. In: Revista de Processo Civil. n. 22, ano VI, abril-junho de 1981.

CRUZ E TUCCI, José Rogério. Tempo e Processo. São Paulo: Revista dos Tribunais 1997.

CUNHA, Leonardo Carneiro da. A Assistência no Novo Código de Processo Civil Brasileiro. In: DIDIER Jr., Fredie (Coord.). Coleção Novo CPC: doutrina selecionada. Parte Geral. Salvador: Jus PodiVm, 2016.

CUNHA, Sérgio Sérvulo da. Ação Possessória contra Réu Inominado. In: Revista de Processo. vol. 94. São Paulo: Revista dos Tribunais, 2000.

A Nova Proteção Possessória. Disponível em http://www.servulo.com.br/pdf/possessoria.pdf.

DA MATTA, Roberto. As Raízes da Violência no Brasil: reflexões de um antropólogo social. In: PAOLI, Maria Célia (Org.). A Violência Brasileira. São Paulo: Editora Brasiliense, 1986.

DANTAS, Bruno. Entrevista. Revista Eletrônica CONJUR, maio de 2010. Disponível em https://www.conjur.com.br/2016-jul-03/entrevista-bruno-dantas-ministro-tcuprofessor.

DANTAS, Bruno. Teoria dos Recursos Repetitivos. São Paulo: Revista dos Tribunais, 2014.

DANTAS, Marcus Eduardo de Carvalho. Função Social da Tutela Possessória em Conflitos Fundiários. In: Revista Direito GVOL. São Paulo. 9(2), pp. 465-488. Juldez. 2013. 
DANTAS, San Tiago. Programa de Direito Civil. vol. III. Rio de Janeiro: Rio, 1979.

DIDIER Jr., Fredie; CABRAL, Antonio do Passo; CUNHA, Leonardo Carneiro da. Por uma nova teoria dos Procedimentos Especiais: Dos procedimentos às técnicas. Salvador: JuspodiVm, 2018.

DIDIER Jr., Fredie. Curso de Direito Processual Civil. vol. 1. Salvador: Jus PodiVm, 2016.

- Situações Jurídicas Coletivas Passivas: o objeto das ações coletivas passivas. In: Revista Eletrônica de Direito do Estado. nº 26, abril/maio/junho de 2011, Salvador.

- Sobre dois importantes, e esquecidos, princípios do processo: adequação e adaptabilidade do procedimento. In: Academia de Direito Processual Civil. Disponível em http://www.abdpc.org.br/abdpc/.

DIDIER Jr., Fredie. CUNHA, Leonardo Carneiro da. Curso de Direito Processual Civil. vol. 3. Salvador: Jus PodiVm, 2016.

DIDIER, Fredie; ZANETTI, Hermes. Curso de Direito Processual. vol. 4. Salvador: JusPodiVm. 2016.

DIDIER Jr., Fredie; ZANETI Jr., Hermes. O CPC/2015 e a reconvenção em processo coletivo. In: Processos Coletivos. vol. 8. Salvador: JusPodiVm, 2016.

DIDIER, Fredie; ZANETI Jr., Hermes, OLIVEIRA, Rafael Alexandria de. Notas sobre Decisões Estruturantes. In: Processos Estruturais. Salvador: JuspodiVm, 2017.

DINAMARCO, Cândido Rangel. A Instrumentalidade do Processo. São Paulo: Malheiros, 2009.

Fundamentos do Processo Civil Moderno. São Paulo: Revista dos Tribunais, 1986.

. Fundamentos do Processo Civil Moderno. São Paulo: Malheiros, 2002.

. Instituições de Direito Processual Civil. vol. I. São Paulo: Malheiros, 2009.

. Instituições de Direito Processual Civil. vol. II. São Paulo: Malheiros, 2002.

. Litisconsórcio. São Paulo: Malheiros, 2009.

DINAMARCO, Pedro da Silva. Ação Civil Pública. São Paulo: Saraiva, 2001.

. Las Acciones Colectivas passivas en el Codigo Modelo de Proccesos Colectivos para Iberoamericana. In: La tutela de los Derechos Difusos, Colectivos e Individuales Homogeneos: hacia un código modelo para iberoamerica. México: Porrua, 2004.

DWORKIN, Ronald. Levando os Direitos a Sério, Trad. Nelson Boeira. São Paulo: WMF Martins Fontes, 2010. 
EID, Elie Pierre. Litisconsórcio Unitário: Fundamentos, estrutura e regime. São Paulo: Revista dos Tribunais, 2016.

FABRÍCIO, Adroaldo Furtado. Justificação Teórica dos Procedimentos Especiais. Disponível em http://www.abdpc.org.br/abdpc/artigos/Adroaldo\%20Furtado\%20Fabr\%C3\%ADcio (3)formatado.pdf. Acesso em 20/09/2017.

FABRÍCIO, Adroaldo Furtado. In: WAMBIER, Teresa Arruda Alvim (Org.). Breves Comentários ao Novo Código de Processo Civil. São Paulo: Revista dos Tribunais, 2016.

FABRÍCIO, Adroaldo Furtado. In: WAMBIER, Teresa Arruda Alvim (Coord.). Primeiros Comentários ao Novo Código de Processo Civil: Artigo por artigo. São Paulo: Revista dos Tribunais, 2015.

FACHIN, Luiz Edson. O Estatuto Constitucional da Proteção Possessória. In: FARIAS, Cristiano Chaves de (Org.). Leituras Complementares de Direito Civil: O Direito Civil Constitucional em Concreto. Salvador: JuspodiVm, 2007.

FALCÃO, Joaquim de Arruda. Conflito de Direito de Propriedade: In: Invasões urbanas. Rio de Janeiro: Forense, 1984.

. Cultura Jurídica e Democracia: a favor da democratização do Judiciário. In: Direito, Cidadania e Participação. LAMOUNIER, Bolívar (Org.). São Paulo: T.A. Queiroz, 1981.

. Democratização e Serviços Legais: Ocupações Urbanas. In: FALCÃO, Joaquim (Org.). Invasões Urbanas: conflito de Direito de Propriedade. Introdução. Rio de Janeiro: Editora FGV, 2008.

. De pés no chão, encharcados: nota à segunda edição. In: FALCÃO, Joaquim (Org.). Invasões Urbanas: conflito de direito de propriedade. Rio de Janeiro: Editora FGV, 2008.

FARIAS, Cristiano Chaves; ROSENVALD, Nelson. Direitos Reais. Salvador: JusPodiVm, 2007.

A Atividade Processual do Curador Especial e a Defesa do Revel Citado Fictamente. In: Revista Jus Navegandi. Teresina, ano 5, n. 46, 1 out, 2000. Disponível em https://jus.com.br/artigos/798/a-atividade-processual-do-curador-especial-e-adefesa-do-revel-citado-fictamente.

FARIA, José Eduardo. A Definição do Interesse Público. In: Processo Civil e Interesse Público: o processo como instrumento de defesa social. São Paulo: Revista dos Tribunais, 2003.

Justiça e Conflito. São Paulo: Revista dos Tribunais, 1992. 
Ordem Legal X Mudança Social a crise do Judiciário e a formação do magistrado. In: FARIA, José Eduardo. (Org.). Direito e Justiça: a função social do Judiciário. São Paulo: Ática, 1997.

FELSTINER, W. L. F; ABEL, R. L.; SARAT, A. The emergence and transformation of disputes: naming, blaming, claiming. Law and Society Review, Salt Lake City, vol. 15 , n. $3 / 4$.

FERRAZ Jr., Tércio Sampaio. O oficial e o Inoficial: ensaio sobre a diversidade de universos jurídicos temporal e especialmente concomitantes. In: Invasões Urbanas: conflito de Direito de Propriedade. Rio de Janeiro: FGV, 2008.

FERNANDES, Edésio. A Produção Socioeconômica, política e jurídica da informalidade urbana. In: Manual de Regularização Fundiária. Instituto Pólis, 2002. Disponível em http://polis.org.br/uploads/949/949.pdf. FERNANDES, Fernando Lavres. Os discursos sobre as Favelas e os Limites ao Direito à Cidade. Cidades. Presidente Prudente: Grupo de Estudos Urbanos, 2(3), jan.-jun, 2005.

FERNANDES, Reinaldo de Francisco. A Legitimação para as Demandas Coletivas no Processo do Trabalho: A legitimação sindical privilegiada. Dissertação (Mestrado). Faculdade de Direito da Universidade de São Paulo, 2010.

FERRARO, Marcella Pereira. Litígios Estruturais: algumas implicações da Publicidade no Processo. In: Processos Estruturais. Salvador: JuspodiVm, 2017.

FIGUEIRA Jr., Joel Dias. Liminares nas Ações Possessórias. São Paulo: Revista dos Tribunais, 1995.

FISS, Owen. FISS, Owen. Fazendo da Constituição uma Verdade Viva. In: ARENHART, Sérgio; JOBIM, Marco Felix. Processos Estruturais. Salvador: JusPodiVm, 2017.

Um Novo Processo Civil: estudos norte-americanos sobre jurisdição, constituição e sociedade. Trad. Carlos Alberto Salles. São Paulo: RT, 2004.

FIX, Mariana. Parceiros da Exclusão. São Paulo: Boitempo, 2001.

FONSECA, José Eduardo da. Legislação de Terras. Revista Forense, n. 38, 1922.

FONTES, Rafaela Seixas. Acesso à Justiça: a experiência dos Sem-Teto da Bahia. Disponível em: http://www.arcos.org.br/artigos/acesso-a-justica-a-experiencia-domovimento-dos-sem-teto-da-bahia/.

FORNACIARI, Flávia Hellmeister Clito. Representatividade Adequada nos Processos Coletivos. Tese (Doutorado). Faculdade de Direito da Universidade de São Paulo. São Paulo, 2010.

FUKASSAWA, Fernando. Regularização Fundiária Urbana. São Paulo: Saraiva, 2013. 
GAJARDONI, Fernando. Flexibilização Procedimental. In: MENDES, Aluisio Gonçalves de Castro (Org.). Programa de Estudos Avançados em homenagem ao Ministro Arnaldo Esteves de Lima. Julho de 2016.

. Os Conflitos Coletivos pela Posse de Imóveis no Novo CPC. In: Jota. Disponível em https://www.jota.info/opiniao-e-analise/colunas/novo-cpc/os-conflitoscoletivos-pela-posse-de-imoveis-no-novo-cpc-04072016.

Os Procedimentos Simplificados e Flexibilizados no Novo CPC. In: MACEDO, Lucas Buril de. [et. al.] (Org.). Coleção Novo CPC. Parte Geral. Jus PodiVm: Salvador: 2016.

GARAPON, Antonie. Bem Julgar: ensaio sobre o ritual Judiciário. Trad. Pedro Filipe Henriques. Lisboa: Instituto Piaget, 1997.

GARAVITO, César Rodríguez; FRANCO, Diana Rodríguez. Cortes y Cambio Social. Cómo la Corte Constitucional transformo el despaziamiento forzado em Colombia. Centro de Estudos de Derecho, Justiciay Sociedad, Dejusticia, Bogotá, 2010.

GALANTER, Marc. Acesso à Justiça em um Mundo de Capacidade Social em Expansão. In: Revista Brasileira de Sociologia do Direito. Porto Alegre, ABraSD, vol. 2, n. 1, jan/jun, 2015.

. Why the "haves" come out ahead: speculations on the limits of legal change. Law and society, vol. 9:1, Aldershot, Dartmouth, 1994.

GAVRONSKI, Alexandre Amaral. Técnicas extraprocessuais de tutela coletiva: a efetividade da tutela coletiva fora do processo judicial. São Paulo: RT, 2010.

GIDI, Antonio. A Class actions como instrumento de tutela coletiva dos direitos: as ações coletivas em uma perspectiva comparada. São Paulo: Revista dos Tribunais, 2007.

GIL, Hernandes. La Función Social de la Posesión. Madrid: Alianza Editorial, 1969.GIRARDI, Eduardo Paulo. Proposição teórico-metodológica de uma Cartografia Geográfica Crítica e sua aplicação no desenvolvimento”. Tese (Doutorado). Programa de Pós-Graduação em Geografia e no Núcleo de Estudos, Pesquisas e Projetos de Reforma Agrária (NERA). Unesp de Presidente Prudente. Disponível em http://www2.fct.unesp.br/nera/atlas/index.htm.

GODINHO, Robson Renault. O Ministério Público e novo Código de Processo Civil: alguns tópicos. In: GODINHO, Robson Renault; COSTA, Susana Henriques da (Coord.). Repercussões do NCPC: Ministério Público. Salvador: JusPodiVm, 2017.

GOHN, Maria da Glória. Sociologia dos Movimentos Sociais. São Paulo: Cortez, 2014.

GOMES NETO, José Mário Wanderley. O Acesso à Justiça em Mauro Cappelletti: análise teórica desta concepção como "movimento" de transformação das estruturas do Processo Civil brasileiro. Porto Alegre: Sérgio Antonio Fabris, 2005. 
GRAU, Eros Roberto. A Ordem Econômica na Constituição de 1988. São Paulo: Malheiros, 2003.

. Parecer. In: STROZAKE, Juvelino José. (Org.). A Questão Agrária e a Justiça. São Paulo: Revista dos Tribunais, 2000.

GRILLO, Marcelo Gomes Franco. Direito Processual e Capitalismo. São Paulo: Dobra Universitária/Outras Expressões, 2017.

GRINOVER, Ada Pellegrini. A coisa julgada no litisconsórcio facultativo unitário: O exemplo de ações coletivas e individuais no campo da saúde. In: AURELLI, Arlete Inês et. al. (Coord.). O Direito de estar em juízo e a coisa julgada: estudos em homenagem a Thereza Alvim. São Paulo: Saraiva. 2014.

. Ações Coletivas para a Tutela do ambiental. In: Revista de Processo, n. 44. São Paulo: RT.

- Ações Concorrentes: Pluralidade de Partes legítimas à impugnação de um único ato. In: LIEBMAN, Enrico Tullio. Eficária e autoridade da sentença e outros escritos sobre coisa julgada. Trad. Alfredo Buzaid e Benvindo Aires, com notas de Ada Pellegrini Grinover. Rio de Janeiro: Forense, 2006.

. A Representação adequada nas ações coletivas brasileiras: uma proposta. In: Revista de Processo, ano 27, out-dez 2002.

. Da class actions for damages à ação civil brasileira: os requisitos de admissibilidade. In: O Processo: Estudos \& Pareceres. São Paulo: DPJ, 2009.

. Código de Processo Civil Coletivo. Um modelo para países de direito escrito. In: MAZZEI, Rita; NOLASCO, Rita. Processo Coletivo. São Paulo: Quartier Latin, 2005 .

. Código Brasileiro de Defesa do Consumidor Comentado. vol. II: Processo Coletivo. Rio de Janeiro: Forense. 2012.

. Eficacia y autoridad de la sentencia: el Código Modelo y la Teoría de Liebman. In: GIDI, Antônio (Coord.). La Tutela de direitos difusos, direitos colectivos, $e$ individuales homogêneos: hacia um codigo modelo para Iberoamerica Mexico: Porrua, 2004.

- Novas Tendências do direito processual: de acordo com a Constituição Federal de 1988. Rio de Janeiro: Forense, 1990.

. Parecer sobre legitimidade da Defensoria Pública para o ajuizamento de ação civil pública. In: Revista da Defensoria Pública do Estado de São Paulo, ano 4, n. 2, jul/dez, 2011.

. O controle jurisdicional de políticas públicas. In: GRINOVER, Ada Pellegrini; WATANABE, Kazuo (Coord.). O controle jurisdicional de políticas públicas. Rio de Janeiro: Forense, 2011. 
. "Significado social, político e jurídico da tutela de interesses difusos". In: Repro, São Paulo: RT, n. 97, 2000.

. [et al.] Teoria Geral do Processo. São Paulo: Malheiros, 2008.

. O Processo em sua Unidade. vol. II. Rio de Janeiro: Forense. 1984.

GRINOVER, Ada Pellegrini et. al. In: Os Processos Coletivos nos Países do Civil Law e do Common Law: uma análise de Direito Comparado. São Paulo: Revista dos Tribunais, 2008.

GUIMARÃES, Antonio Sérgio Alfredo. Classes, Raças e Democracia. São Paulo: Editora 34, 2012.

GIDI, Antonio. A Class actions como instrumento de tutela coletiva dos direitos: as ações coletivas em uma perspectiva comparada. São Paulo: Revista dos Tribunais, 2007.

. A Representação adequada nas ações coletivas brasileiras: uma proposta. In: Revista de Processo, ano 27, out-dez 2002.

- Código de Processo Civil Coletivo. Um modelo para países de direito escrito. In: MAZZEI, Rita; NOLASCO, Rita. Processo Coletivo. São Paulo: Quartier Latin, 2005.

GODINHO, Robson Renault. O Ministério Público e novo Código de Processo Civil: alguns tópicos. In: GODINHO, Robson Renault; COSTA, Susana Henriques da (Coord.). Repercussões do NCPC: Ministério Público. Salvador: JusPodiVm, 2017.

GAVRONSKI, Alexandre Amaral. Técnicas extraprocessuais de tutela coletiva: a efetividade da tutela coletiva fora do processo judicial. São Paulo: RT, 2010.

HÄBERLE, Peter. Hermenêutica Constitucional: Sociedade Aberta dos intérpretes da Constituição. Traduzido por Gilmar Ferreira Mendes. Porto Alegre: Sérgio Antonio Fabris, 1997.

HADFIELD, Gillian. The price of law: how the Market for lawyers distorts the justice system. 98 MICH. L. VER. 953, 2000.

HAZARD, Geoffrey C. Jr. E TARUFFO, Michele. American Civil Procedure: an introduction. New Haven: Yale, 1993.

HERNANDEZ GIL, Antônio. La Función de la Posesión. Madrid: Alianza, 1969.

HOLO, Robert E. Comment. Defendant Class Actions: the failure of Rule 23 and a Proposed Solution. UCLA Law Review. 38, 223, 266-68, 1990.

IHERING, Rudolf Von. Teoria Simplificada da Posse. Trad. Pinto de Aguiar. Salvador: Livraria Progresso, 1957. 
JACOB NETTO, Fernando. Tutela Processual da Posse. Dissertação (Mestrado). Faculdade de Direito da Universidade de São Paulo. São Paulo, 2013.

JUNQUEIRA, Eliane Botelho. Acesso à Justiça: um olhar retrospectivo. In: Revista Estudos Históricos, n. 18, 1996.

JUNQUEIRA, Eliana Botelho; RODRIGUES, José Augusto de Souza. Pasárgada revisitada: sociologia: problemas e práticas, Rio de Janeiro, n. 12, 1992.

JUNQUEIRA, Eliane; VIEIRA, José Ribas; FONSECA, Maria Guadalupe Piragibe da. Juízes: retrato em preto \& branco. Rio de Janeiro: LetraCapital, 1997.

KALVEN Jr., Harry; ROSENFIELD, Maurice. The contemporary function of the class suit. The University of Chicago Law Review. vol. 8. 1941.KATO, Shelma Lombardi de. A crise do direito e o compromisso da libertação. In: FARIA, José Eduardo (Org.). Direito e Justiça: a função social do judiciário. São Paulo, 1989.

KLONOFF, Robert. Class Actions and other multiparty litigation. St. Paul: Thomson West, 2004.

LANUSSE, Pedro P. Proceso Jurisdiccional Eficaz. Buenos Aires: Ad-Hoc, 2005.

LAURIS, Elida. Entre o social e o político: a luta pela definição de acesso à justiça em São Paulo. Revista Crítica de Ciências Sociais. n. 89/2009. Disponível em https://rccs.revues.org/1464.

LEAL, Rogério Gesta. Direito Urbanístico: Condições e Possibilidades da Constituição do Espaço Urbano. Rio de Janeiro: Renovar, 2003.

LEONEL, Ricardo de Barros. Manual de Processo Coletivo. São Paulo: Revista dos Tribunais, 2011.

. Novo CPC: o Ministério Público e a jurisdição voluntária. In: GODINHO, Robson Renault; COSTA, Susana Henriques da (Coord.). Repercussões do NCPC: Ministério Público. Salvador: JusPodiVm, 2017.

LÉPORE, Paulo Eduardo. Rolezinhos e a Violação de Direitos das Crianças e dos Adolescentes. In: Dossiê Rolezinhos: Shopping Centers e Violação de Direitos Humanos no Estado de São Paulo. Dissertação (Mestrado). Faculdade de Direito de Ribeirão Preto (FDRP). Ribeirão Preto: Universidade de São Paulo, 2015.

LIMA, Frederico Rodrigues Viana. Um Novo Processo Civil para uma nova Defensoria Pública. In: SOUSA, José Augusto Garcia de (Coord.). Repercussões do Novo CPC: Defensoria Pública. Salvador: JuspodiVm, 2015.

LOPES, Reinaldo de Lima. A Definição do Interesse Público. In: SALLES, Carlos Alberto de. (Org.). Processo Civil e Interesse Público: O processo como instrumento de defesa social. São Paulo: Revista dos Tribunais, 2003. 
LOUREIRO, Francisco Eduardo. A Propriedade como Relação Jurídica Complexa. Rio de Janeiro: Renovar, 2003.

MACHADO, Antônio Cláudio da Costa. Código de Processo Civil interpretado e anotado. São Paulo: Manole, 2006.

MACHADO, Antônio Alberto. O Rolezinho e as Novas Catedrais. In: SEVERI, Fabiana Cristina. In: Dossiê Rolezinhos: Shopping Centers e Violação de Direitos Humanos no Estado de São Paulo. Dissertação (Mestrado). Faculdade de Direito de Ribeirão Preto (FDRP). Ribeirão Preto: Universidade de São Paulo. 2015.

MAGALHÃES, Alex Ferreira. O Direito das Favelas no Contexto Pós-Programa FavelaBairro: uma recolocação do debate a respeito do "Direito de Pasárgada". Tese (Doutorado). Instituto de Pesquisa e Planejamento Urbano e Regional da UFRJ. Rio de Janeiro, 2010.

MAIA, Digo Campos Medina. Ação Coletiva Passiva. Rio de Janeiro: Lumen Iuris, 2009. Ação Coletiva Passiva: o restrospecto histórico de uma necessidade presente. In: GRINOVER, Ada Pellegrini (Coord.) [et al.] Direito Processual Civil e o Anteprojeto do Código Brasileiro de Processos Coletivos. São Paulo: Revista dos Tribunais, 2007.

MAIA, Maurílio Casas. A Intervenção de Terceiros da Defensoria Pública nas Ações Possessórias Multitudinárias do NCPC: colisão de interesses (art. $4^{\circ}$, a, V, Lei 80/94) e posições processuais dinâmicas. In: MACÊDO, Lucas Burli (Org.). Coleção Novo CPC. Parte Geral. Salvador: JuspodiVm, 2016.

MALUF, Carlos Alberto Dabus. Curso de Direito Civil. 39. ed. São Paulo: Saraiva, 2009.

MANCUSO, Rodolfo de Camargo. A Ação Civil Pública como Instrumento de controle das chamadas Políticas Públicas. In: MILARÉ, Édis (Coord.). Ação Civil Pública: lei 7.347/85 - 15 anos. São Paulo: RT, 2002.

. Da jurisdição coletiva à tutela judicial plurindividual: evolução da experiência brasileira com as demandas seriais. In: Direito processual constitucional. Brasília: Gazeta Jurídica, 2016.

Interesses Difusos: conceito e legitimação para agir. São Paulo: Revista dos Tribunais, 2004.

MARCATO, Antonio Carlos. Procedimentos Especiais. São Paulo: Atlas, 2016.

MARÉS, Carlos Frederico; SAUER, Sérgio. (Coord.). Estudo sobre soluções alternativas para conflitos fundiários agrários e tradicionais. Casos Emblemáticos $e$ Experiências de Mediação. Análise para uma cultura institucional de soluções alternativas de conflitos rurais. Centro de Estudos sobre o sistema de justiça. Brasília: Ministério da Justiça, 2013. 
MARICATO, Ermínia. Para entender a Crise Urbana. São Paulo: Expressão Popular, 2015.

. Pósfacio. Planeta Favela. São Paulo: Boitempo, 2006.

MARINONI, Luís Guilherme. Novas Linhas do Processo Civil. São Paulo: Malheiros, 1996.

. O "problema" do incidente de resolução de demandas repetitivas e dos recursos extraordinário e especial repetitivos. In: Revista de Processo. vol. 249. Ano 40. São Paulo: Revista dos Tribunais, nov. 2015.

. Técnica Processual e Tutela dos Direitos. São Paulo: Revista dos Tribunais, 2010.

MARINONI, Luiz Guilherme; ARENHART, Sérgio Cruz; MITIDIERO, Daniel. Curso de Processo Civil: tutela dos direitos mediante procedimentos diferenciados. São Paulo: Revista dos Tribunais, 2017.

MARINONI, Luiz Guilherme. ARENHART, Sérgio Cruz. Prova. São Paulo: Editora dos Tribunais, 2009.

MARINONI, Luiz Guilherme; BECKER, Laércio A. A Influência das relações pessoais sobre a advocacia e o processo civil brasileiros. Jus Navegandi. Teresina, ano 8, n. 286, 2004. Disponível em http://jus.com.br/artigos/5066/a-influencia-das-relacoespessoais-sobre-a-advocacia-e-o-processo-civil-brasileiros.

MARINONI, Luiz Guilherme; MITIDIEIRO, Daniel. Código de Processo Civil Comentado: Artigo por artigo. São Paulo: Revista dos Tribunais, 2008.

MARINONI, Luiz Guilherme; MITIDIERO, Luiz Guilherme. O Projeto do CPC: crítica e propostas. São Paulo: Revista dos Tribunais, 2010.

MARKY, Thomas. Curso Elementar de Direito Romano. São Paulo: Milesi, 1981.

MARQUES, José Frederico. Instituições de Direito Processual Civil. vol. II. Rio de Janeiro: Forense, 2000.

Instituições de Direito Processual Civil. vol. III. Campinas: Millennium, 2000.

MAZZILLI, Hugo Nigro. MAZZILI, Hugo. MAZZILLI, Hugo Nigro. A Atuação do Ministério Público no Processo Civil. Disponível em www.mazzilli.com.br. . A Defesa dos Interesses Difusos em Juízo. São Paulo: Saraiva. 2013.

. Réus Incertos ou Desconhecidos no Processo Civil. In: Justitia. São Paulo. 47(128): jan/mar. 1995.

MELUCCI, A. Challenging Codes: Collective Action in the Information Age. Cambridge: Cambridge University Press, 1996. 
MENDES, Aluisio Gonçalves de Castro. Ações Coletivas no Direito Comparado e Nacional. São Paulo: Revista dos Tribunais, 2010.

- A Legitimação, a representatividade adequada e a certificação nos processos coletivos e as ações coletivas passivas. In: Revista de Processo. Ano 37. vol. 209. Julho/2012.

MENDES, Aluísio Gonçalves de Castro; TEMER, Sofia. O incidente de resolução de demandas repetitivas do novo Código de Processo Civil. In: ZANETI Jr., Hermes (Org.). Repercussões do Novo CPC: Processo Coletivo. vol. 08. Salvador; JuspodiVm, 2016.

MENDES Jr., João de Almeida. Direito Judiciário Brasileiro. Rio de Janeiro: Freitas de Barros, 1960.

MENEZES, Rafael Lessa V. de Sá. Crítica do Direito à Moradia e das Políticas Habitacionais. Rio de Janeiro: Lumen Iuris, 2017.

MIAGUSKO, Edson. Movimentos de Moradia e Sem-Teto em São Paulo: experiências no contexto do desmanche. Tese (Mestrado). Programa de Filosofia, Letras e Ciências Humanas na Universidade São Paulo, 2008.

MICHELI, Gian Antonio. La carga de la prueba. Buenos Aires: Ejea, 1961.

MILAGRES, Marcelo de Oliveira. Ações Possessórias e o Ministério Público. In: GODINHO, Robson Renault; COSTA, Susana Henriques da (Org.). Repercussões do Novo CPC: Ministério Público. Salvador: Jus PodiVm, 2017.

MILANO, Giovanna Bonilha. Conflitos Fundiários Urbanos e Poder Judiciário. Curitiba: Íthala, 2017.

MILLAR, Robert Wyness. Los Principios Formativos del Procedimento Civil. Buenos Aires: Ediar. 1945.

MIRRA, Álvaro Luís Valery. Ação Civil Pública em defesa do meio ambiente: a representatividade adequada dos entes intermediários legitimados para a causa. In: MILARÉ, Édis. A Ação Civil Pública após 20 anos: efetividade e desafios. São Paulo: Revista dos Tribunais, 2005.

Participação, Processo Civil e defesa do meio ambiente. São Paulo: Letras Jurídicas, 2011.

Participação, Processo Civil e defesa do meio ambiente no direito brasileiro. Tese (Doutorado). Faculdade de Direito da Universidade de São Paulo. Orientador Cândido Rangel Dinamarco, 2010.

MITIDIERO, Daniel. Colaboração no Processo Civil: Pressupostos sociais, lógicos e éticos. São Paulo: Revista dos Tribunais, 2009. 
MONIZ DE ARAGÃO. Comentário ao Código de Processo Civil. vol. II. Rio de Janeiro: Forense. 1974.

MONREAL, Eduardo Novoa. O Direito como Obstáculo à transformação social. Trad. Gérson Pereira dos Santos. Porto Alegre: SAFe, 1988.

MONTENEGRO FILHO, Misael. Ações Possessórias no Novo Código de Processo Civil. São Paulo: Atlas, 2016.

MORABITO, Vince. Defendant Class Actions and the Right to Opt Out: lessons for Canada from the United States. Suke Journal of Comparative \& International Law. vol. 14. ano 197, 2004.

MOREIRA ALVES, José Carlos. Direito Romano. 14. ed. Rio de Janeiro: Forense, 2007. . Posse: Evolução Histórica. Rio de Janeiro: Forense, 1999.

MOREIRA, José Carlos Barbosa. La Igualdad de las partes en el proceso civil. Revista de Processo, São Paulo, n. 44, p. 82, out/dez, 1996.

O Neoprivatismo no Processo Civil. In: Revista de Processo. São Paulo: RT, vol. 30, n. 122, abr., 2005.

. Tutela Sancionatória e Tutela Preventiva. Revista de Processo. In: Temas de Direito Processual. Segunda Série. Saraiva, 1980.MOREIRA, Rafaela Selem. Democratização do Judiciário na cidade do Rio de Janeiro: um estudo sobre o acesso individual e coletivo dos moradores de favela a justiça, contextualizado a luz de uma historia de desigualdades. Dissertação (Mestrado). PUC/RJ, 2011.

MOURA, Alexandrina Sobreira de. Terra do Mangue: invasões urbanas no Recife. Recife: Fundação Joaquim Nabuco, 1990.

MULLENIX, Linda. [et. al]. Os processos coletivos nos países de civil e common law: uma análise de Direito Comparado. São Paulo: RT, 2008.

NEVES, Daniel Amorim Assumpção. Manual de Processo Coletivo. Rio de Janeiro: Editora Método. 2014.

Novo CPC: inovações, alterações e supressões comentadas. São Paulo: Método, 2016.

NERY, Nelson; NERY, Rosa. Código de Processo Civil Comentado. São Paulo: Revista dos Tribunais, 2006.

NERY, Nelson. Curso de Processo Civil. vol. I. São Paulo: Revista dos Tribunais, 2006.

. Princípios do Processo na Constituição Federal. São Paulo: Revista dos Tribunais, 2009. 
NEUHOLD, Roberta dos Reis. Os Movimentos de Moradia e Sem-teto e as Ocupações de imóveis Ociosos: A luta por políticas públicas habitacionais na área central da cidade de São Paulo. Dissertação (Doutorado). Programa de Filosofia, Letras e Ciências Humanas da Universidade de São Paulo. São Paulo, 2009.

NEWAMN, Dwight. Community and collective rights: a theoretical framework for rights held by groups. Oxford: Hart Publishing, 2011.

OLIVEIRA, Carlos Alberto Álvaro. A Garantia do Contraditório. In: Revista de Direito da UFRGS. $\quad$ n. $15,1998 . \quad$ Disponível em http://seer.ufrgs.br/index.php/revfacdir/article/view/70385.

. Do Formalismo no Processo Civil: proposta de um formalismo-valorativo. São Paulo: Saraiva, 2009.

. O Juiz e o Princípio do Contraditório. In: Revista de Processo. 71/31, 1993.

. Procedimento de ideologia no direito processual civil atual. Porto Alegre: Ajuris, n. 33. Março, 1985.

OLIVEIRA, Fabiana Luci de. Cidadania, Justiça e Pacificação. Rio de Janeiro: Gvol. 2014.

. UPPs, Direitos e Justiça: um estudo das favelas do Vidigal. Rio de Janeiro: Gvol. Disponível em: http://bibliotecadigital.fgv.br.

OLIVEIRA, Rogério Alvarez. MP deve intervir nos litígios coletivos pela posse de terra rural ou urbana. Revista Eletrônica Conjur, 17 de outubro de 2016. Disponível em https://www.conjur.com.br/2016-out-17/mp-debate-mp-intervir-litigios-coletivosposse-terra-rural-ou-urbana.

OLIVEIRA, Swarai Cervone de. Poderes do juiz nos processos coletivos. In: GOZZOLI, Maria Clara et al. (Coord.). Em defesa de um novo sistema de processos coletivos: estudos em Homenagem a Ada Pellegrini Grinover. São Paulo: Saraiva. 2010.

ORLANDO, Gomes. Significado da Evolução Contemporânea do Direito de Propriedade. Revista dos Tribunais, vol. 757. Nov., 1998.

OSNA, Gustavo. Nem "tudo", nem "nada" - decisões estruturais e efetivos jurisdicionais complexos. In: Processos Estruturais. Salvador: JuspodiVm, 2017.PANDOLFI, Dulce; GRYNSZPAN, Mario. Poder Público e favelas: uma relação delicada. In: OLIVEIRA, Lúcia Lippi (Org.). Cidade, história e desafios. Rio de Janeiro: Fundação Getúlio Vargas, 2002.

PAOLLELLO, Renata Medeiros. Conflitos Fundiários na Baixada do Ribeira: a posse como direito e estratégia de apropriação. Tese (Mestrado). Universidade Estadual de Campinas. Campinas. Instituto de Filosofia e Ciências Humanas. 1992.

PARSONS, A. Peter; STARR, Kenneth W. Environmental Litigation and Defendant Class Actions: the unrealized viability of rule 23, 4 Ecology L. Q. (1975). 
PAULA, Jônatas Luiz Moreira. A Jurisdição como elemento de inclusão social: revitalizando as regras do jogo democrático. São Paulo: Manole, 2002.

PEREIRA, Caio Mário da Silva. Instituições de Direito Civil. Rio de Janeiro: Forense, 2003.

PERLINGIERI, Pietro. Perfis do Direito Civil. Introdução ao direito civil constitucional. Trad. Maria Cristina de Cicco. Rio de Janeiro: Renovar, 1997.

PEREIRA, Rosalinda P. C. Rodrigues. A Teoria da Função Social da propriedade rural e seus reflexos na acepção clássica de propriedade. In: STROZAKE, Juvelino José. A Questão Agrária e a Justiça. São Paulo: Revista dos Tribunais, 2000.

PEYRANO, Jorge W. El Proceso Civil: Principios y Fundamentos. Buenos Aires: Astrea, 1978.

PIOVESAN, Ana Carolina Cinoca. Acesso à justiça e direito à moradia: uma crítica à atuação do Judiciário nos processos de reintegração de posse no centro da cidade de São Paulo. In: Revista Brasileira de Sociologia do Direito. Porto Alegre, ABraSD, vol. 2, n. 2, p. 106-120, jul./dez., 2015.

PISANI, Andrea Proto. Público e Privado no Processo Civil. Revista da Emerj, vol. 4, n. $16,2001$.

PONTES MIRANDA, Francisco Cavalcanti Pontes de. Comentários ao Código de Processo Civil. Tomo I. Rio de Janeiro: Forense, 1976.

Comentários ao Código de Processo Civil. Tomo III. Rio de Janeiro: Forense, 1973.

Comentários ao Código de Processo Civil. vol. III. São Paulo: Forense, 1974.

PORTANOVA, Rui. Princípios do Processo Civil. Porto Alegre: Livraria do Advogado, 2008.

PORTO, José Roberto Sotero de Mello; CAMPOS, Rodrigo Sardinha de Freitas. Questões sobre a atuação da Defensoria pública nas Ações Possessórias. In: Revista Eletrônica CONJUR. Publicado em 13/04/2017. Disponível em https://www.conjur.com.br/2017-abr-18/tribuna-defensoria-questoes-atuacaodefensoria-acoes-possessorias

PROTO PISANI, Andrea. Appunti sulla giustizia civile. Bari: Cacucci, 1982.

REOLOM, Mônica; CASTRO, Laura Maia de. "Shoppings fecham suas portas para barrar rolezinhos". Estadão. São Paulo. Publicado 16/01/2014. Disponível em http://sao-paulo.estadao.com.br/noticias/geral,shoppings-de-sao-paulo-fechamportas-para-barrar-rolezinhos.

RIBEIRO, Paulo de Tarso Ramos. Direito e Processo: razão burocrática e acesso à justiça. São Paulo: Max Limonad, 2002. 
Razão burocrática e acesso à justiça. Max Limonad: São Paulo, 2002.

RIBEIRO, Romeu Marques. Das Invasões Coletivas: aspectos jurisprudenciais. Porto alegre: Livraria do Advogado, 1998.

RODRIGUES NETO, Nelson. Subsídios para a ação coletiva passiva brasileira. In: Revista de Direito Processual. Ano 32. n. 149. Julho, 2007.

RODRIGUES, Silvio. Direito Civil: direito das coisas. São Paulo: Saraiva, 2003.

ROLNIK, Raquel. Apresentação. In: Cidades Rebeldes: Passe Livre e as Manifestações que tomaram as ruas do Brasil. São Paulo: Boitempo/Carta Maior, 2013.

ROQUE, André Vasconcelos. Class Actions: ações coletivas nos Estados Unidos: o que podemos aprender com eles? Salvador: JusPodiVm, 2013.

ROSSI, Júlio Cesar. Ação Coletiva Passiva. In: Revista de Processo: Ano 36. vol. 198. Agosto, 2011.

RUDINIKI, Rogério. Introdução ao Processo Coletivo Passivo: a experiência do Direito Norte-americano. In: Revista Universitas Jus, vol. 25, n. 2. 2014.

SADEK, Maria Teresa. Acesso à Justiça: um direito e seus obstáculos. Revista USP, vol. 93. 2014.

. Estudos sobre o Sistema de Justiça. Portal das Ciências Sociais (ANPOCS). Disponível em http://www.anpocs.com/index.php/universo/acervo/biblioteca/coletaneas/o-que-lerna-ciencia-social-brasileira-1970-2002/volume-iv/662-estudos-sobre-o-sistema-dejustica/file.

. Judiciário: mudanças e reformas. Estudos Avançados, São Paulo, vol. 18, n. 51, Mai/Ago, 2004.

SALLES, Carlos Alberto. Ações Coletivas: premissas para comparação com o sistema jurídico norte-americano. In: SALLES, Carlos Alberto de (Org.). Processos Coletivos e Tutela Ambiental. Santos: Universitária Leopoldianum, 2006.

. Execução Judicial em Matéria Ambiental. São Paulo: Revista dos Tribunais, 1998.

SANSEVERINO, Milton; KOMATSU, Roque. A Citação no Direito Processual Civil. São Paulo: Revista dos Tribunais, 1977.

SANTOS, Boaventura de Souza. A Sociologia dos Tribunais e a Democratização da Justiça. In: Pela Mão de Alice: o social e o político na pós-modernidade. Porto: Afrontamento, 1994.

. Introdução à sociologia da administração da justiça. In: FARIA, José Eduardo (Org.). Direito e Justiça. A função social do Judiciário. São Paulo: Ática, 1997. 
. Notas sobre a Histórica Jurídico-Social de Pasárgada. In: SOUTO, Cláudio; FALCÃO, Joaquim (Org.). Sociologia \& Direito. São Paulo: Pioneira Thompson, 2002.

O Direito dos Oprimidos: sociologia crítica do direito. Parte 1. São Paulo: Cortez, 2014.

O discurso e o Poder. In: Revista Forense, n. 272, 1980.

O Discurso e o Poder: ensaio sobre a sociologia da Retórica Jurídica. Porto Alegre: Sergio Antônio Fabris, 1988.

.Os Conflitos Urbanos no Recife. Disponível em https://www.google.com/?gws_rd=ssl\#q=+SOUSA+SANTOS\%2C+Boaventura.+ Os+Conflitos+Urbanos+no+Recife. Acesso em 10/12/2016.

SANTOS, E. L. Silva. A Desumanização do Processo Civil, com o perdão do pleonasmo. In: BECKER, L.A.; SANTOS, E. L. Silva. Elementos para uma Teoria Crítica do Processo. Porto Alegre: Sergio Antonio Fabris, 2002.

SANTOS, E. L. Processo Civil e Função Social: duas fábulas para o vazio. In: Elementos para uma teoria crítica. Porto Alegre: Sergio Antonio Fabris, 2002.

SANTOS, Moacir Amaral. Primeiras Linhas de Direito Processual Civil. São Paulo: Saraiva, 1980-1981.

SARMENTO, Daniel. Livres e Iguais. Rio de Janeiro: Lumen Iuris, 2006.

SAULE Jr., Nelson. A Proteção Jurídica da Moradia nos Assentamentos Irregulares. Porto Alegre: Sérgio Antonio Fabris, 2004.

SAULE Jr., Nelson. DI SARNO, Daniela Campos Libório (Coord.). Conflitos Coletivos sobre a Posse e a Propriedade de bens imóveis. Série Pensando o Direito. Ministério da Justiça, 2009.

SEVERI, Fabiana Cristina. Dossiê Rolezinhos: Shopping Centers e Violação de Direitos Humanos no Estado de São Paulo. Dissertação (Mestrado). Faculdade de Direito de Ribeirão Preto (FDRP). Ribeirão Preto: Universidade de São Paulo. 2015. Disponível em http://www.direitorp.usp.br/wp-content/uploads/2015/05/Dossi\%C3\%AARolezinhos.pdf.

SHEN, Francis X. The overlooked utility of the Defendant Class Action. Denver University Law Review, vol. 88, n. 1, 2010.

SICA, Heitor Vitor Mendonça. O Direito de Defesa no Processo Civil: um estudo sobre a posição do réu. São Paulo: Atlas, 2010. . Preclusão Processual Civil. São Paulo: Atlas, 2006. 
Reflexões em torno da Teoria Geral dos Procedimentos Especiais. In: Revista de Processo. vol. 208. São Paulo: Revista dos Tribunais, jun. 2012.

SIDOU, J. M. Othon. Processo Civil Comparado: (histórico e contemporâneo) à luz do código de processo civil brasileiro modificado até 1996. Rio de Janeiro: Forense Universitária, 1977.

SILVA, Carlos Augusto. O Processo Civil como Estratégia de Poder: reflexo da judicialização da política no Brasil. São Paulo: Renovar, 2004.

SILVA, Michel Ferro. Litisconsórcio Multitudinário. Curitiba: Juruá, 2009.

SILVA, Ovídio Baptista da. Curso de Processo Civil. Rio de Janeiro: Forense, 1998.

- Democracia Moderna e Processo Civil. In: GRINOVER, Ada Pellegrini; DINAMARCO, Cândido Rangel; WATANABE, Kazuo. (Org.). Participação e Processo. São Paulo: Revista dos Tribunais, 1988.

. Participação e Processo. In: GRINOVER, Ada Pellegrini; DINAMARCO, Cândido Rangel; WATANABE, Kazuo (Coord.). São Paulo: RT, 1988.

SIMOKOMAKI, Giulia; SANTOS, Maria Celeste Cordeiro dos. Decisões contra legem, um sintoma ou uma saída? In: SANTOS, Maria Celeste Cordeiro dos (Org.). Limites do Direito: Decisões contra legem: Percepções Cognitivas na Interpretação da Norma. Curitiba: Juruá, 2016.

SIQUEIRA, Cleanto Guimaraes. A Defesa no Processo Civil: as exceções substanciais no processo de conhecimento. Belo Horizonte: Del Rey, 1997.

SOARES, André Matos. A Facultatividade no Litisconsórcio Unitário Ativo. Tese (Doutorado). Pontifícia Universidade de São Paulo. São Paulo, 2014.

SOUSA, José Augusto Garcia de. A Defensoria Pública e o Código de Processo Civil de 2015: novos caminhos e responsabilidade para uma instituição enfim essencial. In: JARDIM, Afrânio Silva [et al]. Revista de Direito Processual da UERJ. Rio de Janeiro: Freitas Bastos, 2015.

SOUZA, Adriano Stanley Rocha. A Formação do Processo nas Ações Reipersecutórias Multitudinárias: a citação de réus inominados na petição inicial. Disponível em http://sisnet.aduaneiras.com.br/lex/doutrinas/arquivos/inicial.pdf.

SPEGLER NETO, Theobaldo. O Princípio da Ampla Defesa e a Citação Editalícia: institutos em conflito. In: Revista (RIDB), Ano 2 (2013), n. 5.

STELLITA, Guilherme. Do Litisconsórcio no Direito brasileiro. Rio de Janeiro: Freitas Bastos, 1955.

STROZAKE, Juvelino José. Acesso à Terra e a Lei da Ação Civil Pública. Tese (Doutorado). Faculdade de Direito da Universidade Pontifícia de São Paulo, 2006. 
A Função Social da Propriedade Rural sob a ótica dos direitos difusos e coletivos. Dissertação (Mestrado). São Paulo: Pontifícia Universidade Católica de São Paulo, 2001.

TÁRREGA, Maria Cristina Vidotti Blanco; MAIA, Cláudio Lopes; FERREIRA, Adegmar José. Observatório da atuação do Poder Judiciário nos Conflitos Agrários decorrentes de ocupações de terra por movimentos sociais nos estados do Pará, Mato Grosso, Goiás e Paraná. (2003-2011). Goiânia. Universidade Federal de Goiás, Faculdade de Direito, 2012.

TARUFFO, Michele. Páginas sobre Justicia Civil: proceso y derecho. Madrid: Marcial Pons, 2009.

. Some remarks on group litigation in comparative perspective. Duke Journal of Comparative and International Law. vol. 11. N. 2. 1983.

TASCHER, Susana Pasternak. Favelas em São Paulo: sensos, consensos e contrassensos. In: Caderno Metrópole. vol. 5. São Paulo: PUC/SP, 2001.

TATURCE, Fernanda. Igualdade e Vulnerabilidade no Processo Civil. São Paulo: Forense. 2012.

TEIXEIRA, Sálvio de Figueiredo. Código de Processo Civil Anotado. São Paulo: Saraiva, 1992.

TEIXEIRA DE SOUSA, Miguel. Um Novo Processo Civil Português: à la recherche du temps perdu? In: BRITO, Rita (Coord.). Novos Rumos da Justiça Cível. Coimbra: Centro de Estudos Judiciários, 2009.

TEMER, Sofia. Incidente de resolução de demandas repetitivas. Salvador: JuspodiVm, 2018.

TEPPEDINO, Gustavo. Apresentação. Temas de Direito Civil. Rio de Janeiro: Renovar, 2001.

TIDMASH, Jay. Rethinking Adequacy os Representation. Sholarly Works. Paper 531, 2009.

TORRES, Marcos Alcino de Azevedo. A Propriedade e a Posse: um confronto em torno da função social. Rio de Janeiro: Lumen Iuris, 2007.

TORRES, Marcos de Azevedo. A Propriedade e a Posse: um confronto em torno da função social. Rio de Janeiro: Lumen Iuris, 2007.

TRINDADE, Thiago Aparecido. Ampliando o Debate sobre a Participação Política e a Construção Democrática: o movimento de moradia e as Ocupações de imóveis ociosos no Centro da Cidade de São Paulo. Tese (Mestrado). Universidade de Campinas, 2014.

TRUBEK, David M. The Handmaiden's Revenge: on reading and using the newer sociology of civil procedure. Law and contemporary problems, vol. 51, n. 4, 1988. 
UZELAC, Alan. Direito Processual e Pluralismo Jurídico. Grupos Desfavorecidos de pessoas e uma abordagem ao processo judicial derivado do esbulho possessório e do deslocamento forçado. Como resolver disputas privadas (que não envolvem o Estado) sobre a terra que envolvem membros de grupo em desvantagem, a exemplo dos indígenas, de uma forma justa e garantindo o devido processo Legal? In: Revista Eletrônica de Direito Processual (REDP). Ano 11. vol. 18. Número 2. Maio a Agosto de 2017.

VAINER, Carlos. Quando a Cidade vai às Ruas. In: Cidades Rebeldes: Passe Livre e as Manifestações que tomaram as ruas do Brasil. São Paulo: Boitempo/Carta Maior, 2013.

VIANA, Frederico. Um novo CPC para uma nova Defensoria Pública. In: SOUSA, José Augusto Garcia de. Repercussões do Novo CPC: Defensoria Pública. Salvador: JusPodiVm, 2015.

VIANNA, Luiz Werneck. [et. al.]. Corpo e Alma da Magistratura Brasileira. Rio de Janeiro: Revan, 1997.

VIANA, Silvia. Será que formulamos mal a pergunta? In: Cidades Rebeldes: Passe Livre e as Manifestações que tomaram as ruas do Brasil. São Paulo: Boitempo/Carta Maior, 2013.

VIGLIAR, José Marcelo Menezes. Defendant Class Action brasileira: limites propostos pelo Código Brasileiro de Processos Coletivos. In: GRINOVER, Ada Pellegrini. [et al.] Direito Processual Coletivo e o Anteprojeto de Código Brasileiro de Processos Coletivos. São Paulo: Revista dos Tribunais, 2007.

VIOLIN, Jordão. Ação Coletiva Passiva: fundamentos e perfis. Salvador: JusPodiVm, 2008.

VITORELLI, Edilson. O Devido Processo Legal Coletivo: Dos Direitos aos Litígios Coletivos. São Paulo: Revista dos Tribunais, 2016.

- Tipologia dos Litígios transindividuais: um novo ponto de partida para a tutela coletiva. In: DIDIER Jr. Fredie. Repercussões do Novo CPC. vol. 8. Salvador: JusPodiVm, 2015.

WAMBIER, Teresa Arruda Alvim; WAMBIER, Luiz Rodrigues. Casos Problemáticos: partes ou terceiros? (Análise de algumas situações complexas de dirieto material. In: DIDIER Jr., Fredie; WAMBIER, Teresa Arruda Alvim. Aspectos Polêmicos e Atuais sobre os Terceiros no Processo Civil e assuntos afins. São Paulo: Revista dos Tribunais, 2004.

WATANABE, Kazuo. A conversão da ação individual em coletiva. In: MENDES, Aluísio Gonçalves de Castro (Org.). O Novo Código de Processo Civil: Programa de Estudos Avançados em homenagem ao Ministro Arnaldo Esteves Lima. Rio de Janeiro: Escola de Magistratura Regional Federal 2a Região, 2016. 
In: GRINOVER, Ada Pellegrini; WATANABE, Kazuo; NERY Jr. Nelson (Org). Código Brasileiro de Defesa do Consumidor: comentado pelos autores do anteprojeto. vol. II. Rio de Janeiro: Forense, 2011.

. WATANABE, Kazuo. Cognição no Processo Civil, São Paulo: Saraiva, 2012.

. Tutela Jurisdicional dos Interesses Difusos: a legitimação para agir. In: GRINOVER, Ada Pellegrini (Coord.). A tutela dos interesses difusos, jurisprudência e trabalhos forenses. São Paulo; Max Limonad, 1984.

WOLFSON, Barry. Defendant class actions. Ohio State Law Journal, vol. 38, n. 3 (1997).

WOLKART, Erik Navarro. In: CABRAL, Antônio do Passo; CRAMER, Ronaldo. Comentários ao Novo Código de Processo Civil. Rio de Janeiro: Forense, 2016.

ZANETTI Jr., Hermes. A Teoria Circular dos Planos (Direito Material e Direito Processual). In: DIDIER Jr., Fredie. Leituras Complementares de Processo Civil. Salvador: JusPodiVm, 2009.

Código de Processo Civil de 2015: ruptura do paradoxo entre o Ministério Público da Legalidade e o Ministério Público Constitucional. In: GODINHO, Robson Renault; COSTA, Susana Henriques da (Coord.). Repercussões do NCPC: Ministério Público. Salvador: JusPodiVm, 2017.

Democracia e Judiciário na (re)politização do direito: notas para o papel dos juízes e do Judiciário em um modelo deliberativo-procedimental de democracia (parte 1). In: Poderes do juiz e controle das decisões judiciais: Homenagem à professora Teresa Arruda Alvim Wambier. São Paulo: Revista dos Tribunais, 2008.

ZAVASKI, Teori Albino. A Tutela da Posse na Constituição e no Novo Código Civil. In: Revista Direito e Democracia. vol. 05. n. 1. Canoas. $1^{\circ}$ semestre 2004.

ZUFELlATO, Camilo. Ação Coletiva Passiva no Direito Brasileiro: necessidade de regulação legal. In: GOZZOLI, Maria Clara [et al.] Em defesa de um novo sistema de Processos Coletivos: Estudos em Homenagem a Ada Pellegrini Grinover. São Paulo: Saraiva. 2010.

. A participação da Defensoria Pública nos processos coletivos de hipossuficientes: da legitimidade ativa à intervenção ad coadjuvantum. In: RÉ, Aluisio Iunes Monti Ruggeri (Org.). Temas Aprofundados da Defensoria Pública. Salvador: JusPodiVm, 2013.

. A Proteção Jurídica de Grupos Sociais. In: Dossiê Rolezinhos: Shopping Centers e a Violação de Direitos Humanos no Estado de São Paulo. Dissertação (Mestrado). Faculdade de Direito de Ribeirão Preto (FDRP). Ribeirão Preto: Universidade de São Paulo, 2015.

YEAZELL, Stephen. From medieval group litigation to the modern class action. New Haven and London: Yale University Press. 1987. 
Group Litigation and Social Context: toward a history of the class action. 77 Colum. L. Ver. 866, 880 (1977).

\section{OUTRAS FONTES}

AGÊNCIA DE NOTÍCIAS DO INSTITUTO BRASILEIRO DE GEOGRAFIA E ESTATÍSTICA (IBGE). Pesquisa Nacional por Amostra de Domicílios (Pnad). Publicado 21/12/2017. Disponível em https://agenciadenoticias.ibge.gov.br/agencianoticias/2013-agencia-de-noticias/releases/18992-pnad-continua-2016-51-dapopulacao-com-25-anos-ou-mais-do-brasil-possuiam-apenas-o-ensino-fundamentalcompleto.html.

DATAlUTA PELA TERRA (Banco de Dados). Relatório Dataluta. 2014/2015. Disponível em http://www2.fct.unesp.br/nera/projetos/dataluta_brasil_2014.pdf.

CDHU - COMPANHIA DE DESENVOLVIMENTO HABITACIONAL E URBANO. Relatório Geral do Programa de Atuação em Cortiços - CDHU, maio de 2012. Disponível em http://www.cdhu.sp.gov.br/download/manual/RelatorioGeralProgramaCorticos.pdf.

CENTRO INTERNACIONAL DE POLÍTICAS PARA O CRESCIMENTO INCLUSIVO; Programa das Nações Unidas para Desenvolvimento (PNUD); Instituto de Pesquisa Econômica Aplicada (IPEA) e Fundo Internacional de Desenvolvimento Agrícola (FIDA)."Perfil da Pobreza: Norte e Nordeste rurais", elaborado em parceria com o Disponível em http://www.ipcundp.org/pub/port/PRB50PT_Perfil_da_pobreza_Norte_e_Nordeste_rurais.pdf

COMISSÃO PARLAMENTAR DE INQUÉRITO (CPI) destinada a apurar as origens, causas e consequências da violência no campo brasileiro. Revista da Associação Brasileira de Reforma Agrária - ABRA, n. 1, vol. 22, 120, 1992.

COMISSÃO PASTORAL DA TERRA. Conflitos no campo. Disponível em http://www.cptnacional.org.br/index.php/component/jdownloads/download/41conflitos-no-campo-brasil-publicacao/14019-conflitos-no-campo-brasil-2015. Acesso em 09/08/2016.

CONSELHO NACIONAL DOS DEFENSORES PÚBLICOS (CONDEGE). Comissão Especial do Direito Social à Moradia e Questões Fundiárias do Condege. Enunciados XIII Congresso Nacional de Defensores Públicos. Disponível em http://www.condege.org.br/.

CONSELHO NACIONAL DE JUSTIÇA. Panorama do Acesso à Justiça no Brasil, de $2004 \quad a$ 2009. Julho de 2011. Disponível em http://www.cnj.jus.br/files/conteudo/arquivo/2016/03/69f08fa6be2b411e6566b84bd c1d4b5a.pdf.

CONSELHO NACIONAL DE JUSTIÇA. Pedido de Providência 000194367.2009.2.0.0000. 
http://www.pge.pa.gov.br/files/u13/ARTIGO\%2010\%20\%20PEDIDO\%20DE\%20 PROVIDENCIA\%20OKK.pdf.

CONSELHO NACIONAL DE JUSTIÇA. Relatório “Justiça em Números”, realizado no ano de 2013. "100 Maiores Litigantes" realizada no âmbito do Conselho Nacional de Justiça, em março de 2011". Disponível em http://www.cnj.jus.br/images/pesquisasjudiciarias/pesquisa_100_maiores_litigantes.pd.

CONSELHO NACIONAL DO MINISTÉRIO PÚBLICO. Relatório da Pesquisa de Satisfação e Imagem do CNMP. 2017. Disponível em http://www.cnmp.mp.br/portal/images/Apresenta\%C3\%A7\%C3\%A3o_da_pesquisa _CNMP_V7.pdf.

ESTUDO TRATA BRASIL - $2015 . \quad$ Disponível em http://www.tratabrasil.org.br/saneamento-no-brasil. Acesso em 20/08/16.

FÓRUM NACIONAL DE REFORMA URBANA. Disponível em http://forumreformaurbana.org.br/manifesto-sobre-a-reforma-do-codigo-deprocesso-civil/.

FUNDAÇÃO JOÃO PINHEIRO. Centro de Estatísticas e informações. Déficit habitacional no Brasil: ano de 2013 e 2014. Belo Horizonte; FJP, 2017.

INSTITUTO BRASILEIRO DE GEOGRAFIA ESTATÍSTICA (IBGE). Censo Agropecuária.

http://www.ibge.gov.br/home/estatistica/economia/agropecuaria/censoagro/).

INSTITUTO BRASILEIRO DE GEOGRAFIA ESTATÍSTICA (IBGE). Censo de 2010. Disponível em http://censo2010.ibge.gov.br/apps/atlas/.

INSTITUTO BRASILEIRO DE GEOGRAFIA ESTATÍSTICA (IBGE). Pesquisa Nacional por Amostra de Domicílios (Pnad), 2009.

INTERVOZES. Vozes Silenciadas: Mídias e Protesto. São Paulo: Intervozes. Disponível em http://intervozes.org.br/arquivos/interliv009vozsmep-baixa.pdf.

IPEA. Instituto de Pesquisa Econômica e Aplicada. Governança e Legislação Urbana. Disponível em http://ipea.gov.br/agencia/images/stories/PDFs/livros/livros/160920_estatuto_cidad e_cap04.pdf.

IPEA. Instituto de Pesquisa Econômica e Aplicada (IPEA). Indicadores Socioeconômicos e a litigiosidade. Brasília, DF, Ipea, 2009.

MINISTÉRIO DA JUSTIÇA. Projeto Pensando em Direito. Conflitos Coletivos sobre a Posse $e$ a Propriedade de Bens Imóveis. Disponível em http://pensando.mj.gov.br/wp-content/uploads/2012/11/07Pensando_Direito.pdf. 
MINISTÉRIO DO DESENVOLVIMENTO AGRÁRIO. Departamento da Ouvidoria Agrária. Manual de Diretrizes Nacionais para a Execução de Mandados Judiciais de Manutenção e Reintegração de Posse. Disponível em http://www.lex.com.br/doc_1677637_PORTARIA_N_587_DE_1_DE_DEZEMBR O_2008.aspx.

MOVIMENTO DOS SEM TERRA. Programa Agrário do MST. IV Congresso Nacional do MST. Lutar, construir e Reforma Agrária Popular. In: MST: universidade e pesquisa. Expressão Popular: São Paulo. 2014.

MINISTÉRIO PÚBLICO DO ESTADO DE SÃO PAULO. Centro de Apoio Operacional Cível e de Tutela Coletiva do Ministério Público do Estado de São Paulo. http://www.mpsp.mp.br/portal/page/portal/cao_urbanismo_e_meio_ambiente/mater ial\%20de\%20apoio.pdf. Acesso em 19/02/1018.

SECRETARIA DE REFORMA DO JUDICIÁRIO. Ministério da Justiça. IV Diagnostico da Defensoria Pública no Brasil. 2015. Disponível em http://www.justica.gov.br/suaprotecao/reforma-do-judiciario/biblioteca/iv-diagnostico-da-defensoria-publica-nobrasil.pdf.

PREFEITURA DE SÃO PAULO. Habita Sampa. Disponível em www.habitasampa.inf.br/. 